\title{
Flow dynamics in a vadose shaft - a case study from the Hochschwab karst massif (Northern Calcareous Alps, Austria)
}

\author{
Eva Kaminsky (D) 1,2*, Lukas Plan (D) ${ }^{1}$, Thomas Wagner (D) ${ }^{3,4}$, Barbara Funk (D) ${ }^{1}$, \\ and Pauline Oberender (D) ${ }^{1}$ \\ ${ }^{1}$ Karst and Cave Group, Natural History Museum Vienna, Burgring 7, 1010, Vienna, Austria \\ ${ }^{2}$ Institute for Soil Physics and Rural Water Management, University of Natural Resources and Life Sciences (BOKU), Vienna, Austria \\ ${ }^{3}$ Institute of Earth Sciences, NAWI Graz Geocenter, University of Graz, Graz, Austria \\ ${ }^{4} \mathrm{Geo5} \mathrm{GmbH}$, Leoben, Austria
}

\begin{abstract}
Karst aquifers are highly vulnerable to contamination due to quick water flow through conduits. Their high heterogeneity and the poorly known infiltration effect of the vadose zone make quantification of recharge processes difficult. This study characterizes the water flow and storage in the upper vadose zone with almost four years monitoring of a permanent stream in a vadose shaft (Furtowischacht). Its small catchment of $4,500 \mathrm{~m}^{2}$ is located in a former glaciated high Alpine environment (Hochschwab, Austria). High discharge fluctuations between 0.002 and $19 \mathrm{l} / \mathrm{s}$, relatively high hydrograph recession coefficients, and transport velocities between 0.0015 and $2.4 \mathrm{~m} / \mathrm{s}$ estimated with salt tracer experiments indicate a highly dynamic discharge behavior. A fast point infiltration through open karren and dolines could be observed for rainfall events and indicates a highly karstified network with a rapid water transmission. Snowmelt periods show only a slower flow component and diffuse infiltration. However, condensation within the conduit system is likely superimposed to this signal. A lumped-parameter rainfall-runoff model is used to simulate the discharge with a dual porosity approach. It indicates a low storage volume, which is in accordance with the estimated storage of $22 \mathrm{~m}^{3}$ (or $5 \mathrm{~mm}$ ), deduced from the recession analyses. In contrary, the physicochemical parameters argue for some storage capability: 1) After an increase of discharge, electric conductivity reacts with an average delay of 50 min; 2) Partly a piston flow can be recognized. These amounts of water may be stored in the partial soil cover alone and therefore the presence of a hydrologically significant epikarst layer is unclear.
\end{abstract}

Keywords: $\quad$ vadose zone, epikarst, karst hydrology, modeling, Eastern Alps

Received 15 January 2021; Revised 14 April 2021; Accepted 16 April 2021

Citation: $\quad$ Kaminsky, E., Plan, L., Wagner, T., Funk, B., Oberender P., 2021. Flow dynamics in a vadose shaft - a case study from the Hochschwab karst massif (Northern Calcareous Alps, Austria). International Journal of Speleology, 50(2), 157-172.

https://doi.org/10.5038/1827-806X.50.2.2375

\section{INTRODUCTION}

Percolation through the vadose zone can have a major effect of the groundwater recharge of a karst aquifer. Large fractures or conduits provide quick water flow paths and are highly vulnerable towards contamination whereas the matrix within the carbonate rock may provide a storage component. For a sustainable groundwater management, the characterization of recharge and transfer through the vadose zone plays an essential role (Perrin et al., 2003; Parise et al., 2018; Poulain et al., 2018).

The uppermost part of the vadose zone is termed epikarst. It consists of weathered carbonate rocks with substantially enhanced and more homogeneously distributed porosity and permeability as compared to the bulk rock below with few spacious conduits (Klimchouk, 2004; Williams, 2008). This results in a drop of the hydraulic conductivity (often referred to as "bottleneck effect"; Ford \& Williams, 2007) and can lead to a temporary aquifer. The storage potential depends on the evolutional state of the epikarst and its connection to the vadose zone below (e.g., Trcek, 2003; Perrin et al., 2007; Exel et al., 2016).

High $\mathrm{CO}_{2}$ concentrations near the surface lead to intense karstification of the carbonate rocks and result in mineralization and in an increase of electrical conductivity (EC) of the water (Ford \& Williams, 2007). Differences in the mineralization of the water can be seen as a function of travel time during which the water can interact with the soil or rock. The combined interpretation of hydro- and chemographs 
enables a better understanding of the response of a karst system (Ford \& Williams, 2007; Doummar, 2012). A well-known approach to gain information on the flow and storage characteristics of karst aquifers is hydrograph recession analysis (e.g., Atkinson, 1977; Smart \& Hobbs, 1986; Fiorillo, 2014; Liu et al., 2016).

In many conceptual karst hydrological models, a dual-porosity system is used to describe the flow characteristics within conduits and the matrix (e.g., Smart and Hobbs, 1968; Perrin et al., 2003; Goldscheider, 2015). The quick responses are caused by hydrologic events, where water rapidly moves through conduits or large fractures. Various karst models have been developed as quantitative approaches to provide a deeper understanding of karst aquifer systems (e.g., Hartmann et al., 2014; Parise et al., 2018). However, modeling these systems is challenging due to the extreme heterogeneity of their hydraulic parameters (e.g., Sauter et al., 2006). Global numerical models, like rainfall-runoff models can be used to reproduce the water flow dynamics highlighted by experimental approaches (e.g., Perrin et al., 2003; Rehrl \& Birk, 2010; Mazzilli et al., 2019). Meteorological data and discharge are the only input parameters needed for lumped rainfall-runoff models and after calibration and validation, parameters provide characteristics about the physical properties and the catchment area (e.g., Hartmann et al., 2014). In karst studies, such models have mostly been applied to spring hydrographs (e.g., Geyer, 2008; Wagner et al., 2013; Höfer-Öllinger, 2020). Only few studies report the use of drip water in caves to directly assess the hydrological behavior of the epikarst (e.g., Perrin, 2003; Liu et al., 2016; Poulain et al., 2018). However, to the author's knowledge, no stream in the upper vadose zone in an alpine catchment has been analyzed so far.

This study focuses on a hydrologic characterization of the upper vadose zone by analyzing a stream in a high alpine vadose shaft in the Hochschwab karst massif. The Hochschwab was chosen as the study site, due to its importance for drinking water supply (Plan, 2016). Its larger springs and groundwater wells provide $60 \%$ of water for the Austrian capital Vienna and 30\% for the city of Graz. Due to the high vulnerability of the karst waters, the Hochschwab is part of the spring's protection zone and an understanding of the aquifer recharge is important for the water quality management (Plan et al., 2010).

We selected a $713 \mathrm{~m}$ deep primarily vertical cave (Furtowischacht) because of its stream relatively close to the surface and its location within the catchment of the most important group of springs called "Kläfferquellen". A Thomson weir was installed in a stream of a vadose canyon $100 \mathrm{~m}$ below the entrance of Furtowischacht. To assess the water dynamics above the weir, an almost four years-long data series of hydrograph and physico-chemical parameters was analyzed. Salt tracer experiments were conducted to delineate the small catchment area and to determine tracer transit times in the upper vadose zone. To simulate and quantify the behavior of discharge / runoff (Q), hydrograph analysis and a numerical rainfall-runoff model GR4J+ (Wagner et al., 2016; cf. Perrin et al., 2003; extended with a snow module of Majone et al. (2010)) was used. Based on this study, the heterogeneity of the water flow and storage is quantified for the upper vadose zone, and the hydrological properties of the epikarst in this glacially modified landscape are discussed.

\section{STUDY SITE}

The study area is located in the Hochschwab massif $80 \mathrm{~km} \mathrm{SW}$ of Vienna in the Austrian province of Styria (Fig. 1). With its $650 \mathrm{~km}^{2}$ areal extent, the up to 2,277 $\mathrm{m}$ a.s.1. high Hochschwab massif is one of the extensive karst plateaus of the Northern Calcareous Alps (Plan, 2016). It has an Alpine climate with annual average temperatures (2017-2019) of c. $4^{\circ} \mathrm{C}$ at Sonnschienalm $(1,524 \mathrm{~m}$ a.s.1.). The average annual precipitation measured at Sonnschienalm over the period 2017 to 2019 is $2,383 \mathrm{~mm}$.

Vorderer Polster with a height of $1,994 \mathrm{~m}$ a.s.1. is located east of the Ebenstein $(2,123 \mathrm{~m}$ a.s.1.) with a glacial cirque called Polsterkar in between. The main entrance to Furtowischacht (UTM 33N: 5,271,884 N / $502,845 \mathrm{E}$ ), opens in a $25^{\circ}$ steep west facing slope of that cirque at $1,785 \mathrm{~m}$ a.s.1. (Fig. 1). Polsterkar is situated above the timberline, and grassy vegetation is fragmentary. The soil cover consists mainly of humus and reaches a thickness of up to $0.3 \mathrm{~m}$ but bare rocks with karren are common. As a result of chemical and physical weathering, different surface karst features are observed, for example dolines and karren features as Kluft-, Rund- or Rillenkarren, whereas in the potential catchment area of the cave, subcutaneous karren are common.

Plan \& Decker (2006) characterized the distribution and the fault dependence of dolines and described the glacial overprint as a dominant factor for the occurrence of many karst features in the Hochschwab massif. In the cirques, the dolines were interpreted mainly as shafts that were truncated by glacial erosion. Two such dolines form the entrances to the Furtowischacht (Fig. 1).

The Hochschwab is part of the Northern Calcareous Alps and is characterized by a complex polyphase tectonic evolution including thin-skin fold and thrust deformation as well as strike-slip faulting dominated by sinistral wrenching along major ENE-trending faults (Bauer et al., 2016).

Furtowischacht is developed in Triassic (Ladinian to Lower Carnian) limestone of the Wetterstein Formation in proximal slope facies (Plan, 2002). This is a middle to bright grey massive and very pure limestone, with abundant crinoid stalks (Bryda et al., 2013). Excluding fault zones, the porosity of the Wetterstein limestone is very low $(0.9 \%$, Bauer et al., 2016). So far, the Furtowischacht was explored to a depth of $713 \mathrm{~m}$ below the entrance level within this lithology. Furtowischacht is mainly bound to a few of the parallel normal faults that cut through the Vorderer Polster (Fig. 1). The most prominent one, which is also visible at the entrances, has an orientation of 125/55 


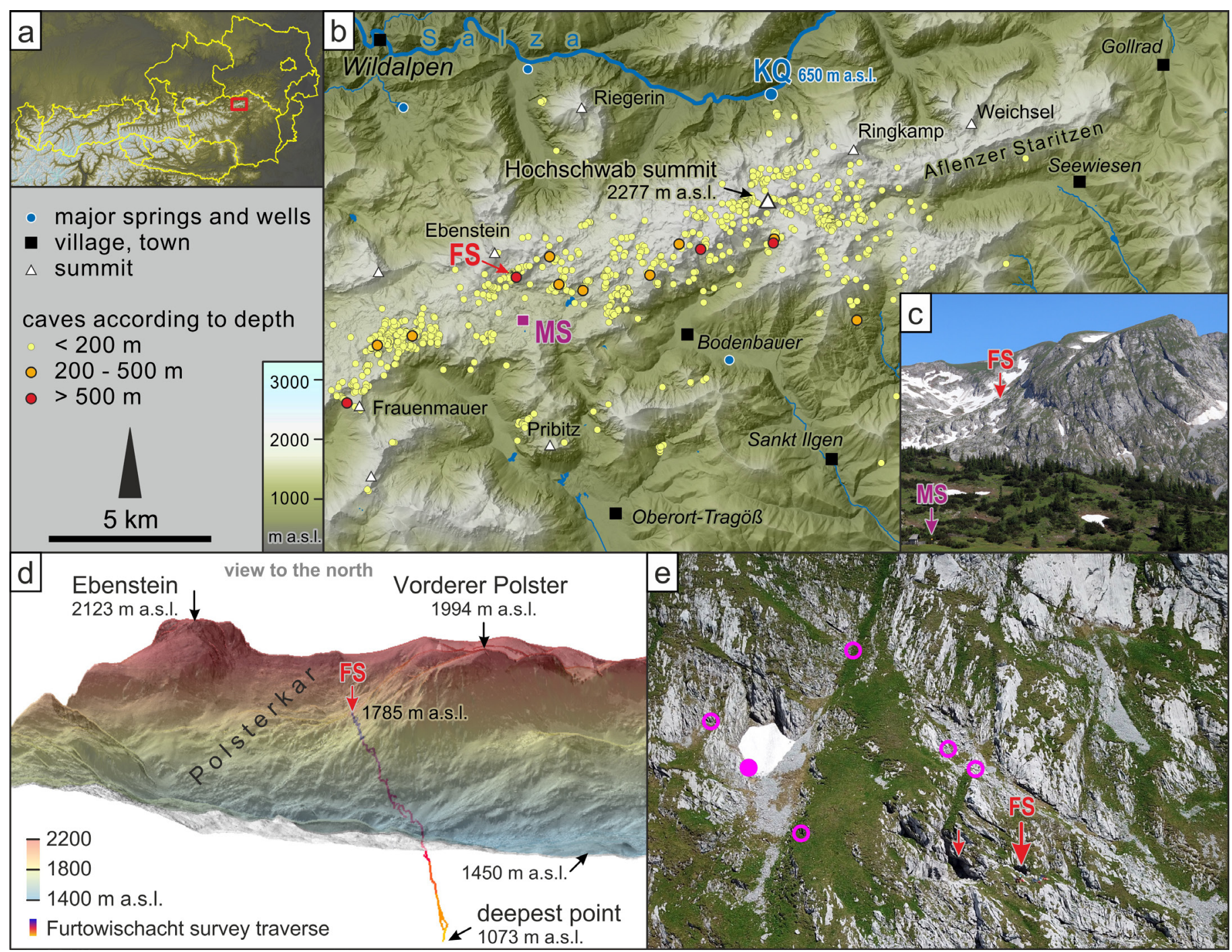

Fig. 1. a) Location of the Hochschwab within the Eastern Alps and Austria. b) The central and eastern Hochschwab massif with its caves, the location of Furtowischacht (FS), the meteorological station at Sonnschienalm (MS), and Kläfferquellen (KQ; modified after Plan, 2016). c) View to the north towards Vorderer Polster behind Sonnschienalm (photo: E. Kaminsky). d) Oblique downward view on the surface around Polsterkar (ALS (c) GIS Land Steiermark). e): Oblique aerial view to the west of the c. $25^{\circ}$ steep slope of Vorderer Polster on 29/6/2019. Entrances of Furtowischacht are marked with arrows (main entrance is labelled). Locations of salt tracer injections are marked with circles; the one that showed a connection to the cave stream has a filled symbol. The distance from the main entrance to the filled circle is $60 \mathrm{~m}$ (photo: L. Plan).

(dip direction/dip). Some parts of the cave are linked to younger faults that strike in NE directions.

In the Quaternary, the Hochschwab was affected by various glaciations. During the Riss glaciation the Hochschwab was partly covered by the Alpine ice stream network. In Würm, only local glaciers appeared (Bryda et al., 2013).

With a mean $Q$ of $5.4 \mathrm{~m}^{3} / \mathrm{s}$, the Kläfferquellen are the biggest springs draining the Hochschwab massif and within the entire Eastern Alps in general (Plan et al., 2010). Q ranges from 0.46 to $49 \mathrm{~m}^{3} / \mathrm{s}$ (Benischke et al., 2016). The size of the catchment is estimated to be $70 \mathrm{~km}^{2}$ and from the elevation dependent ${ }^{18} \mathrm{O}$ fractionation, the mean altitude of the catchment is estimated $1,700 \mathrm{~m}$ a.s.1. (Plan et al., 2010). It is assumed that Furtowischacht is part of the catchment of the Kläfferquellen, which are located $8.5 \mathrm{~km}$ to the $\mathrm{NE}$ and 1,100 m deeper (Plan, 2002).

This cave was chosen for hydrological monitoring, as only $30 \mathrm{~m}$ below the entrance in the so-called Vereinigungsraum a permanently flowing stream is encountered; since its discovery in 1996, it has never been observed to dry up completely. This stream appears from a narrow side canyon less than $10 \mathrm{~m}$ below the entrance level (Fig. 2). The first place that allows the installation of a weir with a data logger is a canyon $100 \mathrm{~m}$ below the entrance (Plan $\&$ Oberender, 2018).

Plan (2016) described the vadose cave development underneath a tube that was formed below a fault controlled phreatic tube. Short and narrow meandering canyons alternate with wide shafts reaching depths of up to $73 \mathrm{~m}$. The cave development is mainly linear with only few side branches and explored to a depth of $713 \mathrm{~m}$. Exploration is still on-going and the phreatic zone has not been reached yet.

\section{METHODS}

\section{Meteorological data}

Most of the data used for this study were obtained at the meteorological station "Hochschwab Sonnschienalm" at $1,524 \mathrm{~m}$ a.s.1. and provided by Vienna Water. Air temperature $\left(\mathrm{T}_{\text {air }}\right)$, precipitation (P), snow height (by ultrasound), and global radiation were recorded every $10 \mathrm{~min}$. This station is located 


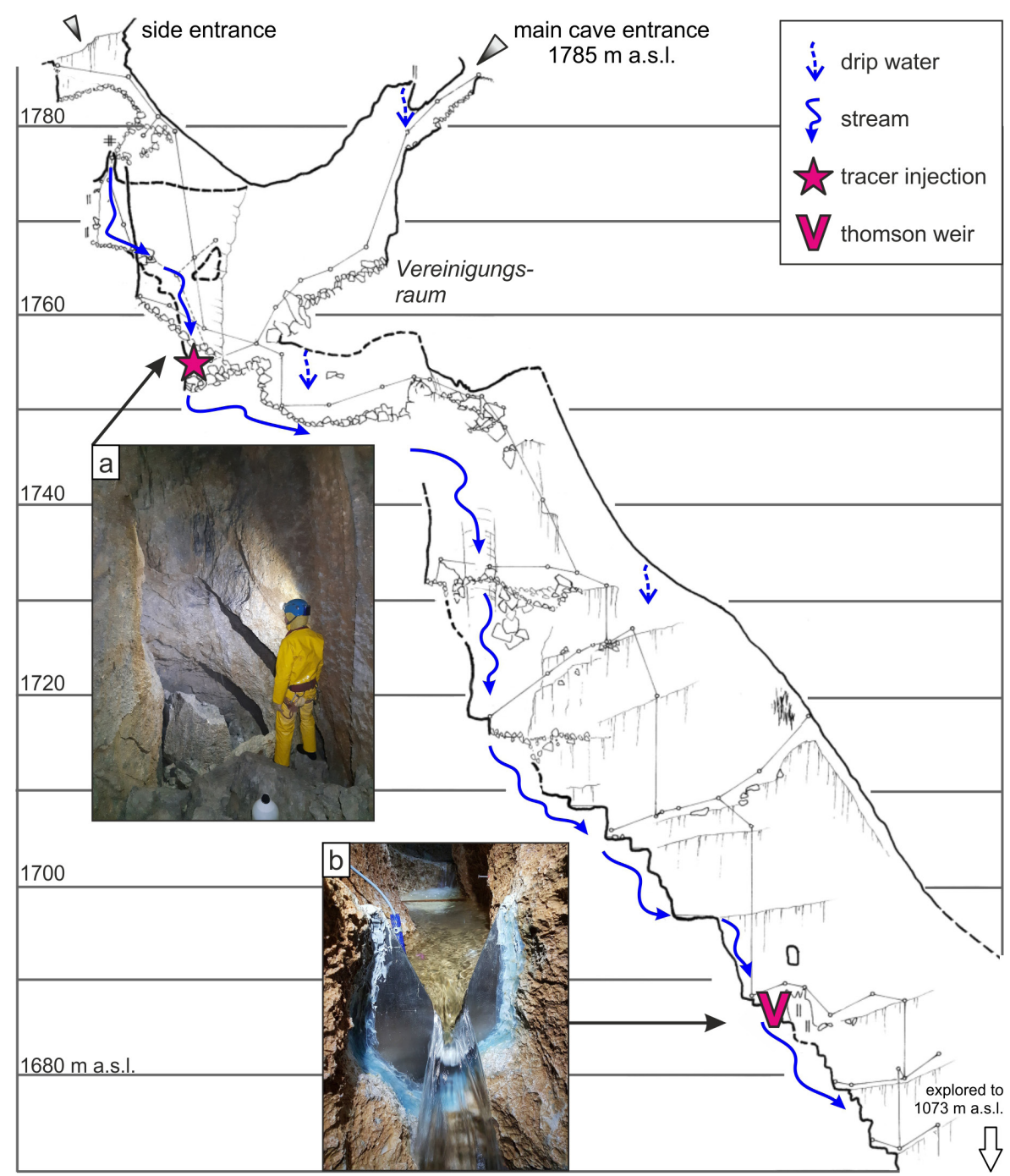

Fig. 2. Extended elevation of Furtowischacht until $130 \mathrm{~m}$ below the entrance (modified after E. Herrmann 1996 - 2003; archive of the Speleologic Society of Vienna and Lower Austria). Canyon with the stream at Vereinigungsraum, where salt tracers were injected (photo: $\mathrm{E}$. Kaminsky). The weir $100 \mathrm{~m}$ below the entrance level. The upper part of the v-notch is $20 \mathrm{~cm}$ wide. (18/11/2019 14:00; 0.8 l/s; photo: L. Plan).

$1.5 \mathrm{~km}$ south and $260 \mathrm{~m}$ below the entrance of Furtowischacht. Since the measurements are not directly from the catchment area of Furtowischacht, they may not be fully representative, due to altitudinal differences in air temperature and precipitation, and orographic effects. Wind-induced loss (undercatch), rainfall intensity, geometry of the gauge, and wetting loss introduce additional uncertainties.

Air temperature generally decreases with rising altitude, and Spötl \& Pavuza (2016) calculated a gradient for the Eastern Alps of $0.5^{\circ} \mathrm{C}$ per $100 \mathrm{~m}$ based on selected climate stations. Due to the altitude difference between the cave entrance and meteorological station, $\mathrm{T}_{\text {air }}$ was adjusted by $-1.3^{\circ} \mathrm{C}$. No elevation correction for $\mathrm{P}$ was made due to scarcity of data.

As evapotranspiration cannot be measured easily in the field simple approaches to compute the potential evapotranspiration (ETp) were used. A simple approach from Oudin et al. (2005), which considers air temperature and global radiation, was used to determine ETp. This approach was already successfully applied by Wagner et al. (2013) in a karst catchment and by Wagner et al. (2016) in a high alpine region.

\section{Thomson weir}

The installation of a Thomson v-notch weir and a SEBA Dipper PTEC data logger was described by Plan $\&$ Oberender (2018). The logger measures water level, water temperature $\left(\mathrm{T}_{\mathrm{w}}\right)$, and $\operatorname{EC}\left(\right.$ at $\left.25^{\circ} \mathrm{C}\right)$. Here we use an almost continuous data series with a time interval of $10 \mathrm{~min}$ or less between 16/12/2016 and $10 / 10 / 2020$.

During 31 field campaigns, water level, $\mathrm{EC}$, and $\mathrm{T}_{\mathrm{w}}$ have been measured manually to calibrate the logger data. To set up a rating curve, $Q$ was determined at various water levels using a bucket. To describe the stream's coherences in the cave, EC was measured at different points with the EC loggers Cond 3310 by $W T W$ or PHD 1 by PEC. Additionally, air temperature was recorded every $2 \mathrm{~h}$ at the weir using a GEO Precision $M-\log 5 \mathrm{~W}$ miniature data logger to check the amplitude of fluctuations.

\section{Catchment of the cave stream and tracer experiments}

The injection of cooking salt extracted from rock salt $(\mathrm{NaCl})$ and measurement of the artificially enhanced EC in Vereinigungsraum and at the weir, have been performed to (1) delineate the catchment 
area, (2) to prove the connection of the streams in Vereinigungsraum and at the weir, and (3) to measure the influences of wet and dry conditions on the transit time between these points. During nine field campaigns, salt (between 50 and $500 \mathrm{~g}$ diluted in water) was injected $30 \mathrm{~m}$ below the cave entrance into the stream in Vereinigungsraum (Fig. 2). The vertical distance from here to the weir is $70 \mathrm{~m}$ and direct 3D-distance is $90 \mathrm{~m}$.

To assess the catchment, salt solutions $(0.5$ to $2 \mathrm{~kg}$ diluted in 3 to 121 of water) were injected into six different surface karren where a direct infiltration was expected, within a maximal distance of $76 \mathrm{~m}$ from the main cave entrance. A mobile EC logger (Cond 3310 by $W T W$ ) was used once during field work to test whether the salt tracer arrives at the stream in Vereinigungsraum. As EC in such an environment cannot be interpreted as a conservative tracer, changes can also be related to dissolution of limestone within the vadose zone. Nevertheless, the information is seen as useful and necessary, as the use of fluorescent tracer is restricted in the catchment of the Vienna Water main.

\section{Data analysis}

The obtained data are processed for time series and event analyses. Descriptive statistics are done for $\mathrm{Q}$, $\mathrm{EC}, \mathrm{P}, \mathrm{T}_{\mathrm{w}}$, and $\mathrm{T}_{\text {air }}$ to get an overview and to classify the data according to event conditions. Depending on the pattern, the data are classified as rain, snowmelt, or snow/rain time series, aiming to quantify time shifts and correlations between the parameters.

Threshold analysis is used to describe the major boundaries and system behavior (e.g., Wagner et al., 2020). For example, the threshold rain value describes the average $\mathrm{P}$, which is needed to observe a response at the weir. For values below the minimum $\mathrm{P}$, it can be assumed that it is stored in the vadose zone above the weir, in the soil, or it evaporated (partly due to vegetation). Hence, the previous event conditions have to be considered. The calculation of the snowmelt is difficult as snow height varies locally due to wind drift and therefore cannot be used for the threshold analysis. $\mathrm{T}_{\text {air }}$ was chosen as a threshold value to estimate when a snowmelt events can be detected at the weir.

\section{Hydrograph recession analysis}

Hydrograph analyses are applied to identify characteristics of the time series. The rate and shape of individual hydrographs provide information about the structure (hydraulic and geometric) and storage characteristics of the drainage system (Ford $\&$ Williams, 2007). The simplest measure to describe the variability of $\mathrm{Q}$ is the ratio between $\mathrm{Qmax}$ and Qmin but it cannot easily be interpreted in terms of aquifer properties (e.g., Stevanović, 2015; Winkler et al., 2016).

The hydrograph recession analysis provides a more detailed insight. Maillet (1905) described the first quantitative analysis of hydrograph recessions with an exponential relation where $\alpha$ describes the recession coefficient (Ford \& Williams, 2007):
$Q_{t}=Q_{0} e^{-\alpha t}$

$\mathrm{Q}_{0} \rightarrow$ initial discharge $[1 / \mathrm{s}]$

$\mathrm{Q}_{\mathrm{t}} \rightarrow$ discharge at time $\mathrm{t}[1 / \mathrm{s}]$

$\alpha \rightarrow$ recession coefficient $[1 / \mathrm{d}]$

$\mathrm{t} \rightarrow$ time $[\mathrm{d}]$

The recession limbs of spring or stream hydrographs in karst aquifers can rarely be described with one equation, therefore the limb can be separated into more segments with different recession coefficients e.g., the separation between quick response and baseflow like in dual porosity models. The quick flow reflects the vulnerability of the aquifer, whereas the baseflow recession can be considered as the drainage from the aquifer storage as discussed in e.g., Birk \& Hergarten (2010), Kresic \& Bonacci (2010), Winkler et al. (2016), and Lui et al. (2016).

For recession analysis the fitting of the recession limb with exponential and quadratic functions are the most common methods (Rehrl \& Birk, 2010). For time series analysis, hydrographs can be separated by using master recession curves (MRC). Here we use, the MRC Tool from Posavec et al. (2017) which is based on a trigonometric approach. Flow duration curves are used to estimate the best separation criteria between MRCs. This curve represents the frequency of each specific $Q$, with a plot of flow rates over the percentage of time instead of a chronological sequence (Malik, 2015).

The volume of the stored water within the aquifer can be calculated through the integration of the Maillet equation under baseflow conditions:

$$
V_{t}=\int_{0}^{\infty} Q_{0} e^{-\alpha t}=c \frac{Q_{0}}{\alpha}
$$

$\mathrm{V}_{\mathrm{t}} \rightarrow$ volume of water stored in the aquifer [1]

$\mathrm{c} \rightarrow$ conversion of seconds to days: 86,400

$\alpha$ and t refer to eq. (1)

Therefore, high a-values indicate a faster response and less storage. The event water volume equates the total runoff volume subtracted by the baseflow (Ford $\&$ Williams, 2007).

\section{RESULTS}

\section{Meteorological data, catchment size, and water budget}

Simple visualization and statistical analyses are used to quantify the meteorological data from the Sonnschienalm station within the observation period. $\mathrm{T}_{\text {air }}$ varies between -24 and $28^{\circ} \mathrm{C}$. The snow height shows the highest value of $3 \mathrm{~m}$ in 2019. Daily $\mathrm{T}_{\text {air }}$ oscillations correlate with the snowmelt, which is visible in the snow height decrease. The annual $\mathrm{P}$ is between 2,145 mm/y (2019) and 2,753 mm/y (2017). Excluding a snowfall event with a $\mathrm{P}$ of $80 \mathrm{~mm} / \mathrm{d}$, the heaviest rainfall was $24 \mathrm{~mm} / \mathrm{h}$ on $14 / 05 / 2017$. The highest rainfall for an entire day was $120 \mathrm{~mm} / \mathrm{d}$ on the 24/10/2018. ETp after Oudin et al. (2005) varies between $426 \mathrm{~mm} / \mathrm{y}$ (2017) and $452 \mathrm{~mm} / \mathrm{y}$ (2018). Nevertheless, ETp is a parameter with high 
uncertainty but generally low absolute value in such high alpine settings. Another important fact is that due to the fragmentary grassy vegetation, the transpiration plays a negligible role and evaporation is dominant.

The catchment area was determined using two different approaches. 1) If we assume that surface runoff is negligible (a justified assumption here since dolines and open karren allow a quick infiltration into the vadose zone), based on $\mathrm{Q}$ and the infiltration ratio (P - ETp; Stevanović, 2015) the catchment is $4,790 \mathrm{~m}^{2}$ on average for the years 2017 to 2020. 2) Additionally, a rough estimation can be made from a simple comparison of the catchment area $\left(70 \mathrm{~km}^{2}\right)$ and Q of the Kläfferquellen in relation to Q measured at the weir. The mean from 2017 and 2018 gives $3,737 \mathrm{~m}^{2}$. For all following calculations, a catchment of $4,500 \mathrm{~m}^{2}$ is assumed. By subtracting ETp (Oudin et al., 2005) from $P$ and using the assumed catchment area, a water budget (i.e., a climatic water balance) is calculated for each year (Table 1). The error between this calculation and the value measured at the weir is between -8.4 and $6.5 \%$. The storage component is not considered within this water budget, since the data suggest that baseflow during each winter is approximately constant.

Table 1. Overview of the meteorological data from the Sonnschienalm and calculations of the water budget assuming a catchment area of $4,500 \mathrm{~m}^{2}$.

\begin{tabular}{|l|c|c|c|}
\hline \multicolumn{1}{|c|}{ Value } & $\mathbf{2 0 1 7}$ & $\mathbf{2 0 1 8}$ & $\mathbf{2 0 1 9}$ \\
\hline $\mathrm{P}[\mathrm{mm} / \mathrm{y}]$ & 2753 & 2251 & 2145 \\
\hline ETp $[\mathrm{mm} / \mathrm{y}]$ & 426 & 452 & 433 \\
\hline Mean Q [1/s] & 0.36 & 0.24 & 0.26 \\
\hline $\mathrm{Q}[\mathrm{mm} / \mathrm{y}]$ & 2523 & 1682 & 1822 \\
\hline Q calc. from water budget [mm/y] & 2327 & 1800 & 1713 \\
\hline Error [\%] & -8.4 & 6.5 & -6.4 \\
\hline
\end{tabular}

\section{Overview of the cave stream data}

Statistic values of the parameters logged at the weir between 12/2016 and 10/2020 are presented in Table 2 . The values are highly variable and the extreme ratio of maximum to minimum discharge (Qmax/Qmin) of 9,500 is striking.

Table 2. Basic water parameters at the weir between 12/2016 and 10/2020 (excluding artificially enhanced EC during salt tracer experiments).

\begin{tabular}{|l|c|c|c|}
\cline { 2 - 4 } \multicolumn{1}{c|}{} & minimum & mean & maximum \\
\hline $\mathrm{Q}[1 / \mathrm{s}]$ & 0.002 & 0.28 & 19 \\
\hline $\mathrm{T}_{\mathrm{w}}\left[{ }^{\circ} \mathrm{C}\right]$ & 2.05 & 2.72 & 4.64 \\
\hline $\mathrm{EC}[\mu \mathrm{S} / \mathrm{cm}]$ & 95 & 158 & 196 \\
\hline
\end{tabular}

In order to assess the characteristics of the water flow regime, $\mathrm{T}_{\text {air }}$, and $\mathrm{P}$ were compared to the hydrograph $\mathrm{Q}$, and chemograph $\mathrm{EC}$ as well as $\mathrm{T}_{\mathrm{w}}$ measured at the weir (Fig. 3). From the repeated manual measurements of EC at various sites along the stream and of the drip water (Fig. 2) one example is given. On $18 / 11 / 2019$, the EC of the cave stream slightly decreased from 152 at Vereinigungsraum to $148 \mu \mathrm{S} / \mathrm{cm}$ at the weir. The drip water closest to the entrance (c. $10 \mathrm{~m}$ below the surface) had an EC of $135 \mu \mathrm{S} / \mathrm{cm}$; melted snow had $2.5 \mu \mathrm{S} / \mathrm{cm}$. This shows that the drip water at very shallow depth is already significantly mineralized and that the cave stream is diluted by less mineralized water along its course.

Looking at the mean monthly parameter values (Fig. 4), we can see that in general, $\mathrm{T}_{\mathrm{w}}$ increases from the last snowmelt to the next winter and that an increasing $Q$ leads to a faster response of $T_{w}$ than of EC. Indeed, $\mathrm{T}_{\mathrm{w}}$ can reach equilibrium between water and the host rock after a few hours. For comparison, the mean $\mathrm{T}_{\text {air }}$ at $-100 \mathrm{~m}$ is $2.4^{\circ} \mathrm{C}$. However, both temperatures show a dynamic behavior and correlate with the event water.

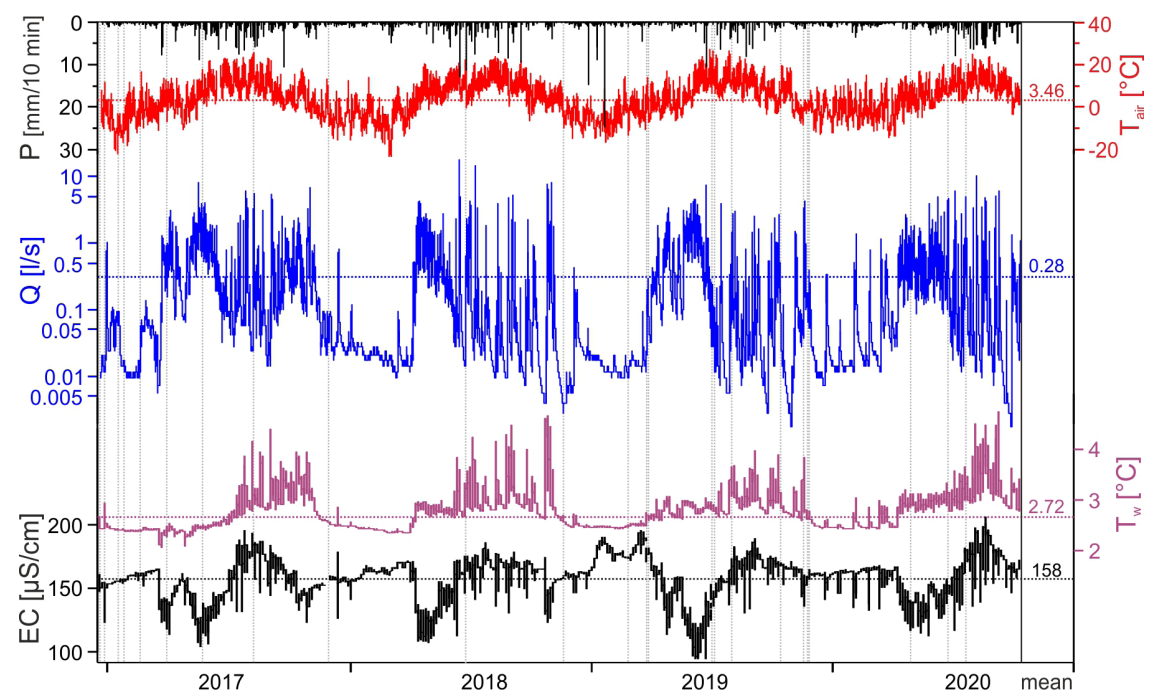

Fig. 3. $T_{\text {air }}$ and $P$ measured at Sonnschienalm compared to $Q, T_{w}$, and $E C$ at the weir in Furtowischacht between 12/2016 and 10/2020. Grey dotted lines show days of fieldwork. Artificially enhanced EC due to salt tracer injection are excluded. 


\section{Seasonal behavior}

In the following, the behavior of the observed values is described according to the seasonal conditions:

(1) Winter conditions: The catchment is covered with snow and $Q$ lacks significant fluctuations, as recharge is negligible (Fig. 3). Typically, Q decreases towards the end of winter but normally not below $0.01 \mathrm{l} / \mathrm{s}$. However, significantly lower Q (down to $0.002 \mathrm{l} / \mathrm{s}$ ) were observed in autumn (see below). During the winter conditions, EC usually increases to roughly $160 \mu \mathrm{S} / \mathrm{cm}$. An exception is the winter 2018/2019 where values were exceptionally high in January (max value $190 \mu \mathrm{S} / \mathrm{cm}$ ). In that winter, snow cover was much thicker, compared to the two other winters. In winter 2016/2017, stable conditions (i.e., low discharge without any major increases) ended in
February after only $30 \mathrm{~d}$. This winter showed the coldest average $\mathrm{T}_{\mathrm{w}} 2.38^{\circ} \mathrm{C}$ and the overall minimum of $2.05^{\circ} \mathrm{C}$ (Fig. 4). This can be explained by an avalanche that filled the shaft down to $-35 \mathrm{~m}$. This was only observed in that winter. The winter $2017 / 2018$ is the longest period (89 d), in which just one small snowmelt event occurred (14/03/2018) until the beginning of April. In the following winter stable conditions ended in March after $80 \mathrm{~d}$, but EC increased only until the end of January and a decrease is visible until 22/03/2019, when a salt tracer experiment was carried out. Afterwards, EC and $\mathrm{T}_{\mathrm{w}}$ slightly increased, and $\mathrm{Q}$ still varied between 0.02 and $0.11 / \mathrm{s}$. Five snowmelt events occurred during the winter 2019/2020, which did not allow a clear delineation of winter conditions.

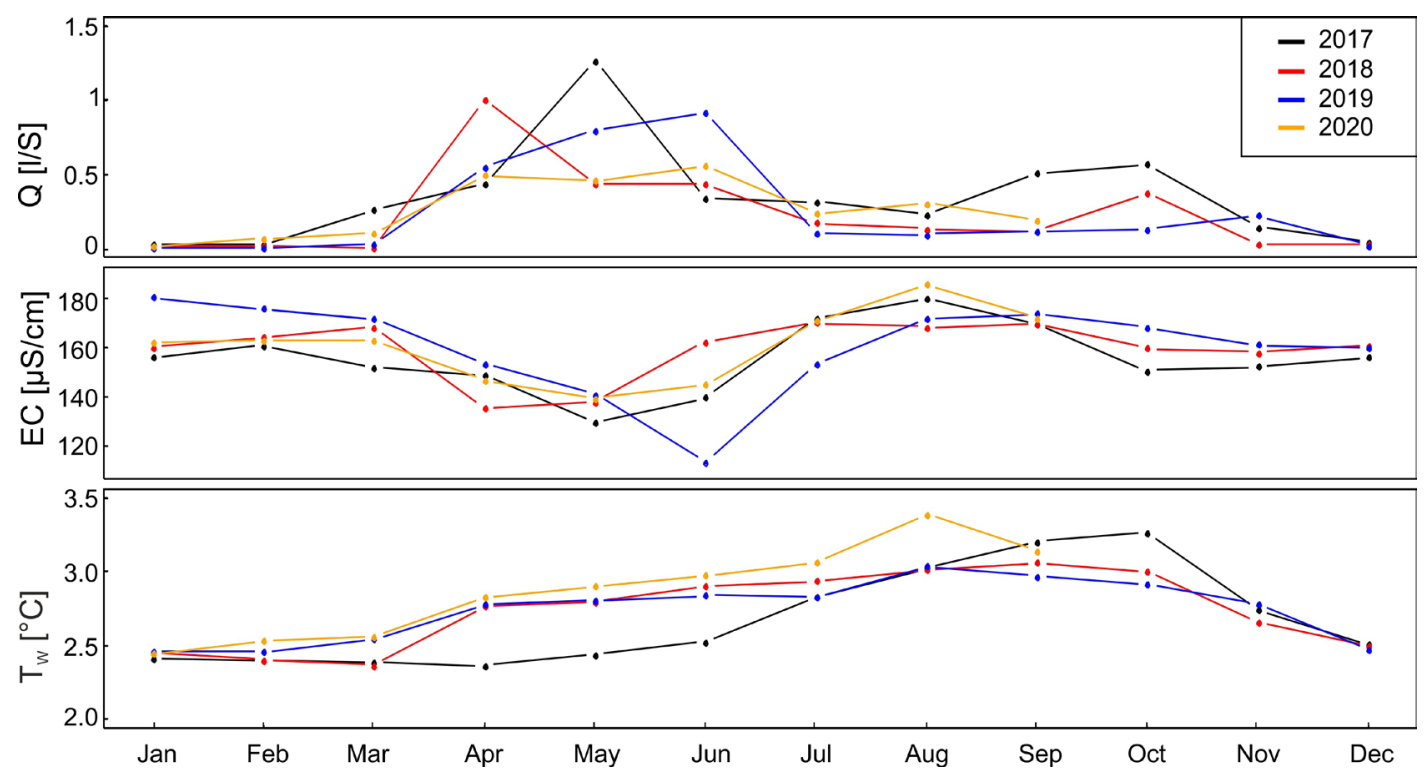

Fig. 4. Mean monthly values for $Q$, EC, and $T_{w}$ for the years 2017 to 2020.

(2) Snowmelt conditions: As soon as $T_{\text {air }}$ increases significantly over $5^{\circ} \mathrm{C}$, snowmelt starts. From Figure 4 it is apparent that the snowmelt starts in the same month in which EC decreases; apparently, the melt water input lowers the stream water mineralization. Different events were selected to determine the daily $\mathrm{T}_{\text {air }}$ maximum needed for a $\mathrm{Q}$ response at the weir, which is at least $5^{\circ} \mathrm{C}$ and on average $7.5^{\circ} \mathrm{C}$. The typical daily oscillations of all parameters and mean monthly values with an increase of $Q$ and $T_{\text {air }}$ and a decrease in EC indicate a start in March or April. If there is no rain event during that time, $Q$ records snowmelt activity and can reach values up to $4.31 / \mathrm{s}$ (on 13/04/2018). Snowmelt produces the highest mean monthly $\mathrm{Q}$ during the year (Fig 4). $\mathrm{T}_{\mathrm{w}}$ shows a different trend. In 2017 (snow from avalanche present within the shaft), it continuously increased while in 2018 , at the beginning of snowmelt, $\mathrm{T}_{\mathrm{w}}$ increased strongly and then decreased continuously over two months with small fluctuations. In 2019, there was no general trend for $\mathrm{T}_{\mathrm{w}}$. The EC signal lags the daily increase of $Q$ between $10 \mathrm{~min}$ and $5 \mathrm{~h} 40 \mathrm{~min}$, with an average of $1 \mathrm{~h} 05 \mathrm{~min}$.

(3) Snow and rain influenced conditions: Usually, between May and June snowmelt and rain events occur concurrently. During that transition period, it is often impossible to distinguish between $\mathrm{P}$ and snowmelt within single events.

(4) Rainy summer conditions: the mean $Q$ during summer is highly dependent on rainfall events and continuously decreases until September or October, although the highest $Q$ peaks are at that time caused by heavy rainfall events. EC decreases during summer, which is in contrast to an increase during winter as expected due to the influence or absence of event water. In general, $\mathrm{Q}$ and $\mathrm{T}_{\mathrm{w}}$ increase whereas EC decreases after $P$ events. The mean lag time between the increases of $Q$ and the followed EC response is 50 min. A threshold value between $\mathrm{P}$ events and a visible increase of $\mathrm{Q}$ at the wire was calculated by linear correlations. On average, $5.6 \mathrm{~mm}$ of $\mathrm{P}$ are necessary for a response at the weir suggesting a quick flow and the minimum observed $\mathrm{P}$ leading to an event response is $1.5 \mathrm{~mm}(\mathrm{n}=80$ events). The time span between Pmax and Qmax is on average $1 \mathrm{~h} 36$ min. The pre-event conditions and type of rain event affect the $\mathrm{Q}$ response at the weir. In general, $\mathrm{P}$ events can be differentiated according to the reaction of the parameters $\mathrm{Q}, \mathrm{T}_{\mathrm{w}}$, and EC into medium rain (a), heavy rain (b), and long and/or low rain (c) events: 
(4a) During heavy rain events $(P>5 \mathrm{~mm} / 10$ min), EC usually first decreases, then substantially increases, sometimes above the initial EC level (an example is given in Figure 5). After the increase of $Q$, the delay in the response of $\mathrm{EC}$ and $\mathrm{T}_{\mathrm{w}}$ is normally $10 \mathrm{~min}$ at maximum. Once a rain event has started, further reactions (multiple peaks) of $\mathrm{Q}, \mathrm{EC}$, and $\mathrm{T}_{\mathrm{w}}$ are simultaneous (or within the time resolution of the logger).

(4b) For medium rain events time shifts range from $<10$ min (lower than the measuring interval) to $1 \mathrm{~h}$ 10 min with an average of 40 min between $P$ and an increase in Q. Usually a short EC decrease is followed by a continuous EC increase. Some events only show an increase in EC. Many rain events last for a couple of days but with a several lulls, resulting in multiple peaks. Depending on the intensity and duration of $\mathrm{P}$, multiple peaks sometimes lead only to an EC increase, without the dip at the beginning.

(4c) Low and/or long rain events mostly follow the same scenario: $Q$ increases first, followed by a continuous rise of $\mathrm{EC}$ and $\mathrm{T}_{\mathrm{w}}$. Time shifts are on average $50 \mathrm{~min}$ and can reach up to $6 \mathrm{~h} 50 \mathrm{~min}$. A typical event from 09/07/2017 (Fig. 6) shows a clear time shift between $Q$ and EC. Initially, both values increase and after the rain event, $Q$ returns to the initial level faster than EC does.

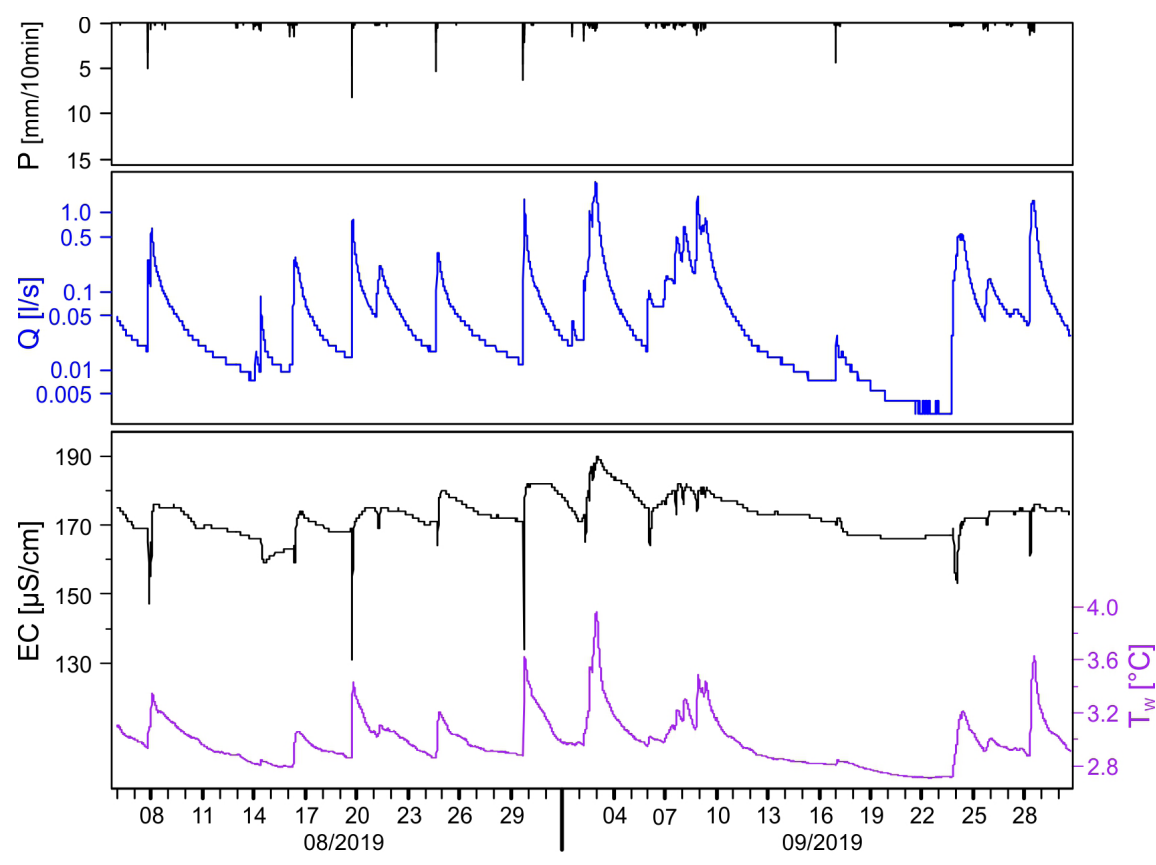

Fig. 5. Time series from $06 / 08$ to $30 / 09 / 2019$. $P$ is compared to $Q, T_{w}$, and EC. During those 56 days, the sum of $P$ was $205 \mathrm{~mm}$ and the average $Q$ was $0.1 \mathrm{l} / \mathrm{s}$.

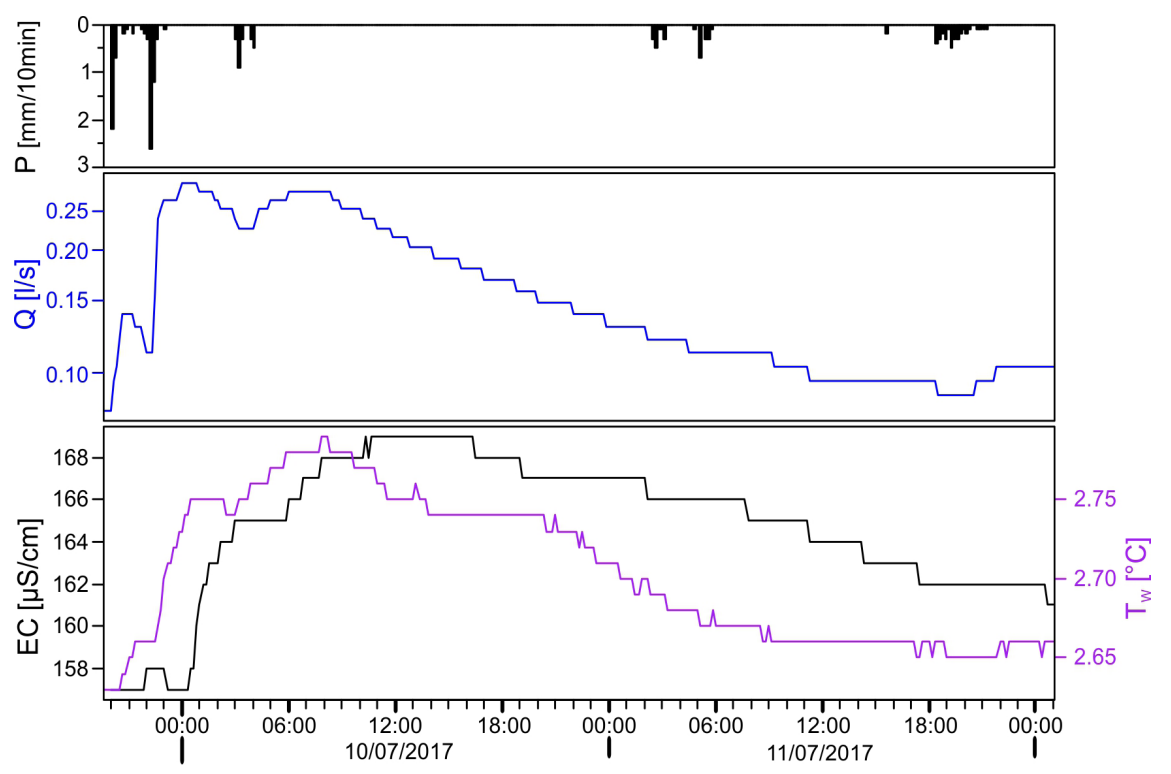

Fig. 6. Example of a typical low rain event on 09/07/2017.

\section{Recession analysis}

Recession analysis was used to quantify the Q behavior classified according to the different conditions (winter, snowmelt, and rainy summer conditions) for each year. The best fitting MRCs for rain conditions could be achieved by separating the recessions into three segments: $\alpha 1$ has the fastest response, $\alpha 2$ shows an intermediate response, and $\alpha 3$ the slowest response, which is related to baseflow. The analysis of snowmelt events has to be treated differently, since they lack quick reactions, and the recession curve is split into $\alpha 2$ and $\alpha 3$ only. The winter conditions are 
characterized only by the $\alpha 3$ since no events occur and due to little to no recharge, baseflow can ideally be observed (Fig. 7 grey rectangle).

The MRC Tool calculates the recessions according to the chosen separation criteria for each event of a time series (Posavec et al., 2017). Figure 7 shows the recessions for each time series and the average recession coefficients for quick-, intermediate- and baseflow. For the snowmelt and rain time series, $\alpha 3$ varies between 0.28 and $0.481 / \mathrm{d}$. During snowmelt in 2018 and 2020, no long recession occurred and therefore the base flow $(\alpha 3)$ is very similar to $\alpha 2$ and can be described with only one coefficient being 2.1 $\pm 0.11 / \mathrm{d}$. For the other two years $(2017,2019)$, the mean for $\alpha 2$ is very similar $(1.91 / \mathrm{d})$. For all rain events, $\alpha 2$ ranges from 1.0 to $1.51 / \mathrm{d}$ while the direct response during $P$ events $(\alpha 1)$ is always $>3.31 / \mathrm{d}$ with a mean of $4.11 / \mathrm{d}$.

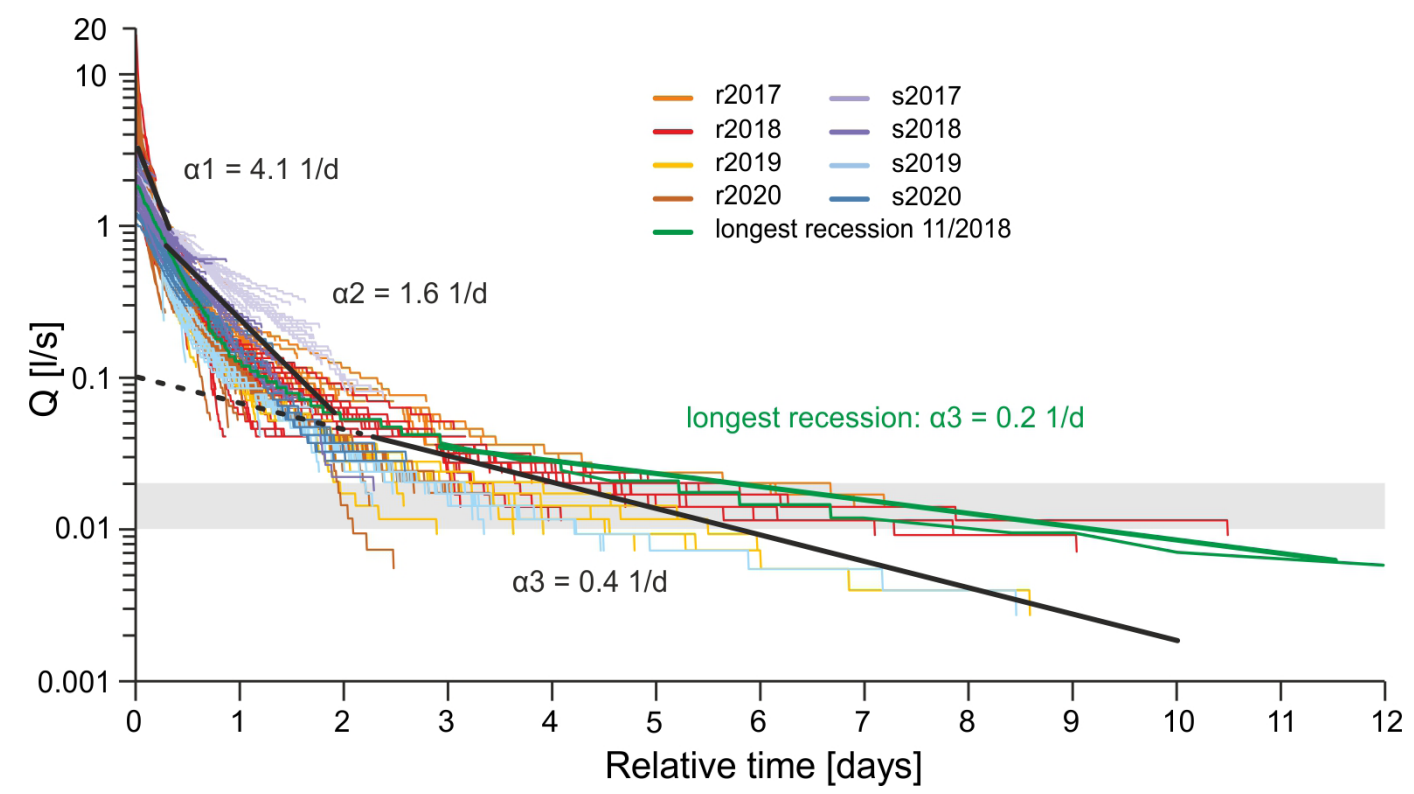

Fig. 7. Semi-log plot of relative time and discharge displaying master recession curves for all time series of summer rain and snowmelt events. The average recession coefficients ( $\alpha 1$ to $\alpha 3$ ) are displayed as black lines; additionally, $\alpha 3$ of the longest recession (11/2018) is shown as green line. For comparison, the grey rectangle indicates the range of the typical winter discharge. The step-like nature of the data, especially at low $Q$ values, are caused by the resolution of the logger that is $1 \mathrm{~mm}$.

The winter conditions only show a baseflow. For $80 \%$ the mean $\mathrm{Q}$ in the winter is between 0.01 and 0.02 1/s (Fig. 7 grey rectangle) with a decrease towards the end of long winter periods (Fig. 3, e.g., 2018/2019). The recession curves for the three analyzed winter conditions (2019/2020 was unstable) show $\alpha 3$ values between 0.08 and $0.21 / \mathrm{d}$. The recession coefficient for the winter conditions is lower than during summer and snowmelt, which shows that no significant event took place, nevertheless the recessions are not longer than $10 \mathrm{~d}$, after which small fluctuations (increases) in $\mathrm{Q}$ are observed.

The analysis of single events with longer recession limbs are of special interest to determine $\alpha$-values that indicate the baseflow. The longest recession (18 d) was detected between 03/11 and 21/11/2018, with an observed Qmin of $0.0021 / \mathrm{s}$ at the end and an $\alpha 3$ of $0.21 / \mathrm{d}$ (Fig. 8).

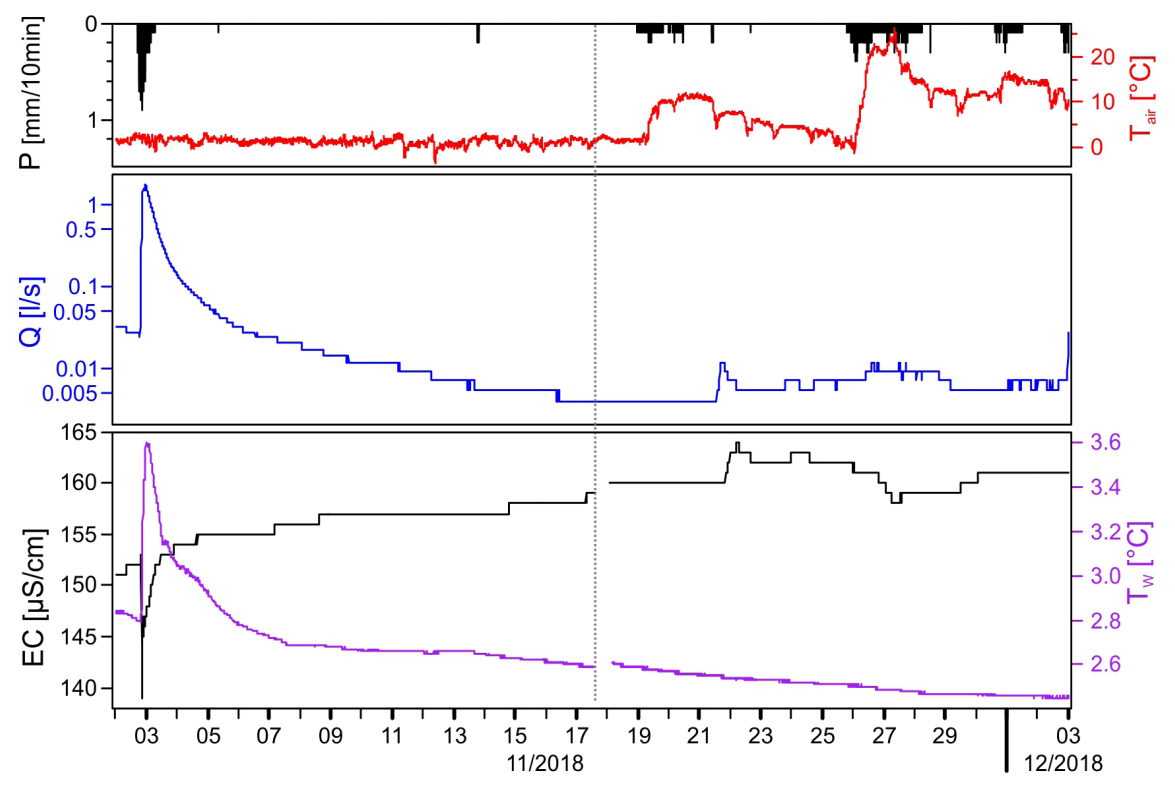

Fig. 8. The longest observed recession started on $03 / 11 / 2018$. The grey dotted line indicates fieldwork including injection of a salt tracer on 17/11/2018. 
For this event, EC shows a sharp increase, possibly due to a piston flow (Ford \& Williams, 2007), followed by an equally sharp decrease due to low mineralized rainwater and an increase above the previous level. $\mathrm{T}_{\mathrm{w}}$ behaves similar to $\mathrm{Q}$ (Fig. 8). During this event, the released water volume was $86 \mathrm{~m}^{3} ; 26 \mathrm{~m}^{3}$ is the storage component (computed from $\alpha 3=0.2$ and $\left.\mathrm{Q}_{0}=0.06 \mathrm{l} / \mathrm{s}\right)$, and $1 \mathrm{~m}^{3}$ is the remaining water stored at the end of the event. Further, a time can be estimated when the overflow of the weir may dry up if no new recharge event occurs or more precisely fall below the resolution of the logger $(1 \mathrm{~mm})$. In the absence of any further recharge (see discussion) this would have happened after $6 \mathrm{~d}$ and the total recession would have lasted for $24 \mathrm{~d}$.

The baseflow reflects the storage volume of the system and is $22 \mathrm{~m}^{3}$ using the average $\alpha 3$ of $0.41 / \mathrm{d}$ and $\mathrm{a} \mathrm{Q}_{0}$ of $0.1 \mathrm{l} / \mathrm{s}$, which is very similar to the one calculated from the longest recession. If we relate these values to the catchment size of $4,500 \mathrm{~m}^{2}$, the thickness of the storage is only about $5 \mathrm{~mm}$ (assuming $100 \%$ effective porosity).

\section{Salt tracer experiments}

All tracers injected in Vereinigungsraum arrived at the weir. The analysis of the breakthrough curves shows that the first detection at the weir $\left(t_{1}\right)$ is highly dependent on $\mathrm{Q}$ and was between c. $7 \mathrm{~min}$ $(\mathrm{Q}=1.1 \mathrm{l} / \mathrm{s})$ and $4 \mathrm{~h} 13 \mathrm{~min}(0.01 \mathrm{l} / \mathrm{s})$ after the injection. The dependency on $\mathrm{Q}$ can be described with the potential function. In Figure 9 the function is used to calculate $t_{1}$ for the observed Qmin and Qmax (Table 3). Further, the transit velocities $\left(\mathrm{v}_{1}\right)$ are calculated using the direct $3 \mathrm{D}$ distance of $90 \mathrm{~m}$ and the measured or extrapolated values of $t_{1}$. The peak transit times $\left(t_{p}\right)$ and the corresponding function are given in Figure 9 as well.

Table 3. Tracer transit times $\left(t_{1}\right)$ and velocity $\left(v_{1}\right)$ based on $Q$ and a 3D distance of $90 \mathrm{~m}$. The measured minimal and maximal values of $t_{1}$ are given. Transit times for the overall Qmax and Qmin are extrapolated and marked with *.

\begin{tabular}{|l|c|c|}
\hline \multicolumn{1}{|c|}{$\mathbf{Q}[\mathbf{1} / \mathbf{s}]$} & $\mathbf{t}_{\mathbf{1}}[\mathbf{s}]$ & $\mathbf{v}_{\mathbf{1}}[\mathbf{m} / \mathbf{s}]$ \\
\hline 19 & $38 \mathrm{~s}^{*}$ & 2.4 \\
\hline 1.1 & c. $420 \mathrm{~s}(\mathrm{c.} 7 \mathrm{~min})$ & 0.2 \\
\hline 0.01 & $1020 \mathrm{~s}(4 \mathrm{~h} 13 \mathrm{~min})$ & 0.006 \\
\hline 0.002 & $61200 \mathrm{~s}^{*}(17 \mathrm{~h})$ & 0.0015 \\
\hline
\end{tabular}

Only one out of six tracer injections into karren at the surface could be clearly observed in the cave. On 29/6/2019 during the end of snowmelt, $2 \mathrm{~kg}$ of salt diluted in 121 water were injected into a Kluftkarre $60 \mathrm{~m}$ north and $10 \mathrm{~m}$ above the main cave entrance (Fig. 1). After $2 \mathrm{~h} 50 \mathrm{~min}$ it could be observed in Vereinigungsraum, having travelled a 3D distance of $66 \mathrm{~m}$, yielding $\mathrm{a} \mathrm{v}_{1}$ of $0.0065 \mathrm{~m} / \mathrm{s}$. Forty-nine minutes later, it was detected at the weir (3D distance of $90 \mathrm{~m})$. Here, in the succession of spacious pits and canyons $\mathrm{v}_{1}$ is almost 5 times higher $(0.03 \mathrm{~m} / \mathrm{s})$. Due to snowmelt, Q (at the weir) rose from $0.031 / \mathrm{s}$ at the time of the injection to $0.2 \mathrm{l} / \mathrm{s}$ when the tracer was detected at the weir. All the other salt tracer injections on the surface did not yield clearly detectable increases in $\mathrm{EC}$ in the cave stream.

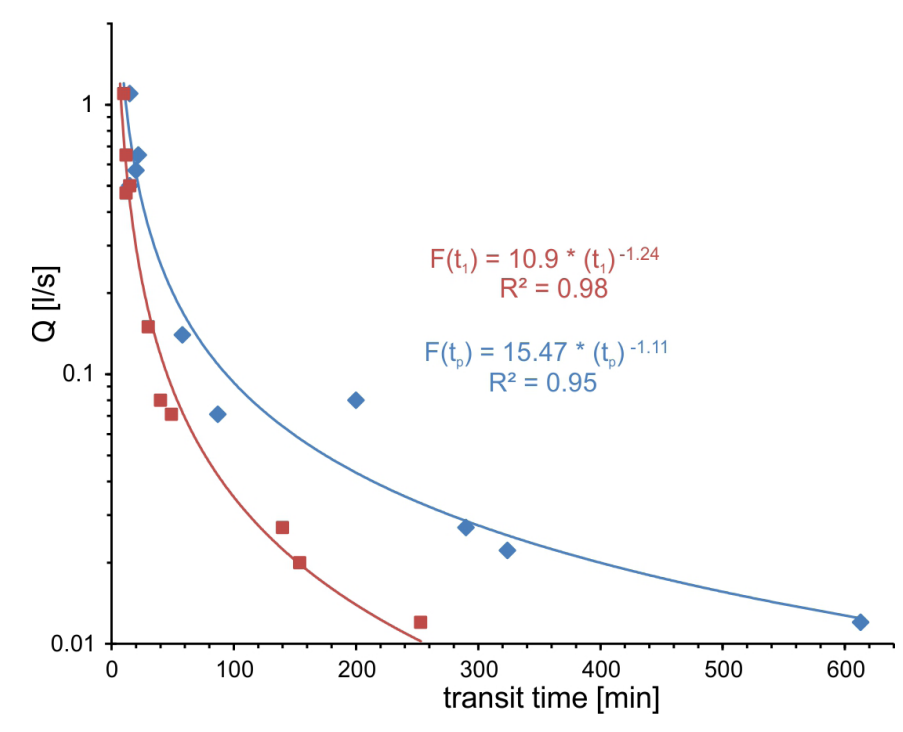

Fig. 9. Transit times of salt tracers injected at Vereinigungsraum for the first detection at the weir (red) and for the peak detection of breakthrough curve (blue).

\section{RAINFALL-RUNOFF MODEL}

Using the results of the data analysis, a conceptual model was formulated, and the data were processed within a numerical bucket type rainfall-runoff model to provide further insights into the storage and flow characteristics. Therefore, Q at the weir is simulated (Qsim) after calibration and validated with the observed Q (Qobs). Perrin et al. (2003) could show that the GR4J is a sufficient tool to satisfactorily model streamflow at daily time steps with a small number of model parameters. This commonly used lumped rainfall-runoff model showed its applicability for 429 sites from semi-arid to tropical catchments (Perrin et al., 2003), complex karst systems (Wagner et al., 2013), and high alpine catchments (Wagner et al., 2016).

Here we use the GR4J and extended it with the snow module from Majone et al. (2010) as proposed by Wagner et al. (2016; named GR4J+; Fig. 10). This simple snow module requires only $\mathrm{T}_{\text {air }}$ and global radiation as input parameters and the adjustment of three free parameters in addition to the four for the GR4J model: 1) Ts = temperature [ $\left.{ }^{\circ} \mathrm{C}\right]$ at which snowfall starts; 2) $\mathrm{Tm}=$ temperature $\left[{ }^{\circ} \mathrm{C}\right]$ at which snowmelt starts; and 3) $\mathrm{Cm}=$ melt factor $\left[\mathrm{mm} /{ }^{\circ} \mathrm{C}\right]$ that allows a certain amount of snowmelt per ${ }^{\circ} \mathrm{C}$ temperature increase from the snow storage.

Used input parameters for the GR4J+ are daily $P$ and ETp calculated after Oudin et al. (2005). The model structure itself is built with four free parameters (Fig. 10): $\mathrm{x} 1$ is the maximum capacity of the production store $[\mathrm{mm}]$ which interacts as a soil moisture accounting store, $\mathrm{x} 2$ water exchange coefficient $[\mathrm{mm}]$ where water can enter or exit the system, x3 maximum capacity of the routing store [mm] which enables long streamflow recession with a non-linear approach, and $\mathrm{x} 4$ time base of hydrograph unit UH1 [d] for the time lag between rainfall and streamflow. $\mathrm{P}$ and/or snowmelt refills the production store, where actual ET occurs based on ETp and water availability in the store. If the maximum capacity 
$\mathrm{x} 1$ of the store is reached, the overflow continuous directly to $\operatorname{Pr}$ (the total quantity of water) without the percolation through the production store. Pr is routed with a fixed separation of 9:1 by UH1 and UH2. The Qsim of UH1 has the time lag $\mathrm{x} 4$ and passes a nonlinear routing store with the maximum capacity $\mathrm{x} 3$. The runoff of UH2 is twice $\mathrm{x} 4$ and linear. Moreover, both flow components (through UH1 and UH2) can be influenced by the water exchange term $\mathrm{x} 2$. Variations of the 1:9 split have been tested by adding it as a free parameter, but no improvement could be achieved, which is in accordance with Perrin et al. (2003) and Wagner et al. (2016).

The model calibration and validation were carried out with a split sample test (Klemens, 1986) by using a mean of the following performance criteria: 1) the classical Nash-Sutcliffe efficiency (NSE, which weight on high flows), 2) log-transformed NSE (weight on intermediate flow), and 3) square-root-transformed NSE (weight on low flow simulations; see Wagner et al., 2016). For the calibration a solver (Gradient descent method) and Qobs was used. NSE of $100 \%$ reflects a perfect match between the Qobs and Qsim. A further performance criterion is the water balance error (wb) where a value below 100\% means that the total Qsim is underestimated compared to the observed $\mathrm{Q}$. The model parameters for the best simulation with a mean NSE of $68 \%$ and $\mathrm{wb}$ of $86 \%$ are given in Table 4 and compared to previous studies (see discussion).

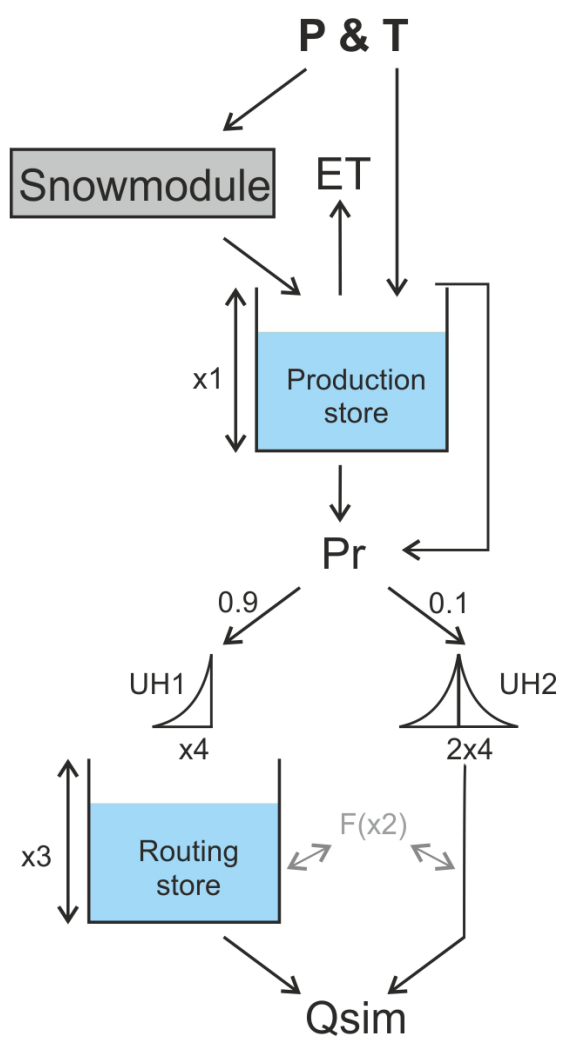

Fig. 10. Conceptual model structure of the extended lumped rainfallrunoff model GR4J+ (modified after Wagner et al., 2016). It is composed of GR4J (Perrin et al., 2003), the snow module based on Majone et al. (2010) and potential evapotranspiration after Oudin et al. (2005). For the description of the parameters, see text.

Table 4. Comparison of simulation results of this study with previous studies: GR4J+ (including the snow module) is used for Furtowischacht and in Wagner et al. (2016). Perrin et al. (2003) used only GR4J and Majone et al. (2010) used the snow module only. For explanations of the values, see text. NSEbar is the mean of NSE Q, NSE $\sqrt{ } Q$ and NSE logQ.

\begin{tabular}{|c|c|c|c|c|}
\hline Value & Furtowischacht & Perrin et al., 2003 & Majone et al., 2010 & Wagner et al., 2016 \\
\hline no. of locations & & 429 & 3 & 3 \\
\hline NSEbar [\%] & 68 & 52 (mean) & - & $64-79$ \\
\hline NSE Q [\%] & 62 & 51 (mean) & $70-90$ & $60-90$ \\
\hline NSE $\sqrt{ } \mathbf{Q}[\%]$ & 71 & 62 (mean) & - & $64-90$ \\
\hline NSE $\log Q$ [\%] & 70 & 58 (mean) & - & $67-80$ \\
\hline wb [\%] & 86 & 79 (mean) & & $91-98$ \\
\hline catchment $\left[\mathbf{k m}^{2}\right]$ & 0.0045 & - & 2,3 , and 82 & $0.7,7$, and 44 \\
\hline $\mathbf{x} \mathbf{1}[\mathbf{m m}]$ & 120 & $350(100-1,200)$ & - & $14-1,513$ \\
\hline $\mathbf{x 2}[\mathrm{mm}]$ & -0.9 & $0(-5-3)$ & - & $-1.0-9.4$ \\
\hline x3 [mm] & 40 & $90(20-300)$ & - & $303-674$ \\
\hline $\mathrm{x} 4$ [d] & 1.0 & $1.7(1.1-2.9)$ & - & $1.1-1.6$ \\
\hline Ts $\left[{ }^{\circ} \mathbf{C}\right]$ & 0.6 & - & $-1--2.9$ & $1.1-2.6$ \\
\hline $\operatorname{Tm}\left[{ }^{\circ} \mathbf{C}\right]$ & 1.1 & - & $0.4-5.5$ & $3.4-4.6$ \\
\hline $\mathbf{C m}\left[\mathbf{m m} /{ }^{\circ} \mathbf{C}\right]$ & 3.7 & - & $0.1-0.3$ & $1.9-3.7$ \\
\hline
\end{tabular}

The general dynamics are well simulated using GR4J+, and some events match very well, for others, like long dry periods especially during summer 2019 Qsim is higher than Qobs (Fig. 11). Some heavy P events are not simulated at all or overestimated. This might probably be caused by the uncertainty in the $\mathrm{P}$ data. Another major source of uncertainty stems from estimating snowmelt, since the snow height has not been directly measured in the field and $\mathrm{T}_{\text {air }}$ is measured $260 \mathrm{~m}$ below the catchment and only corrected with a constant. Quite often during fieldwork, a different weather was observed in the catchment of the cave stream. Despite these limitations, the height of the simulated snow store and measured snow height at the Sonnschienalm station show similar trends.

\section{INTERPRETATION AND DISCUSSION}

Looking at basic water parameters of the cave stream (Table 3), the most striking finding is the extreme range of $Q$ fluctuations at the weir, with a variability degree (Qmax/Qmin) of 9,500. In contrast, this value at the one of Kläfferquellen is 107, therefore the Q of the cave stream is even 89 times more dynamic. The main reason may be that this large spring combines many thousands of such small catchments at various 


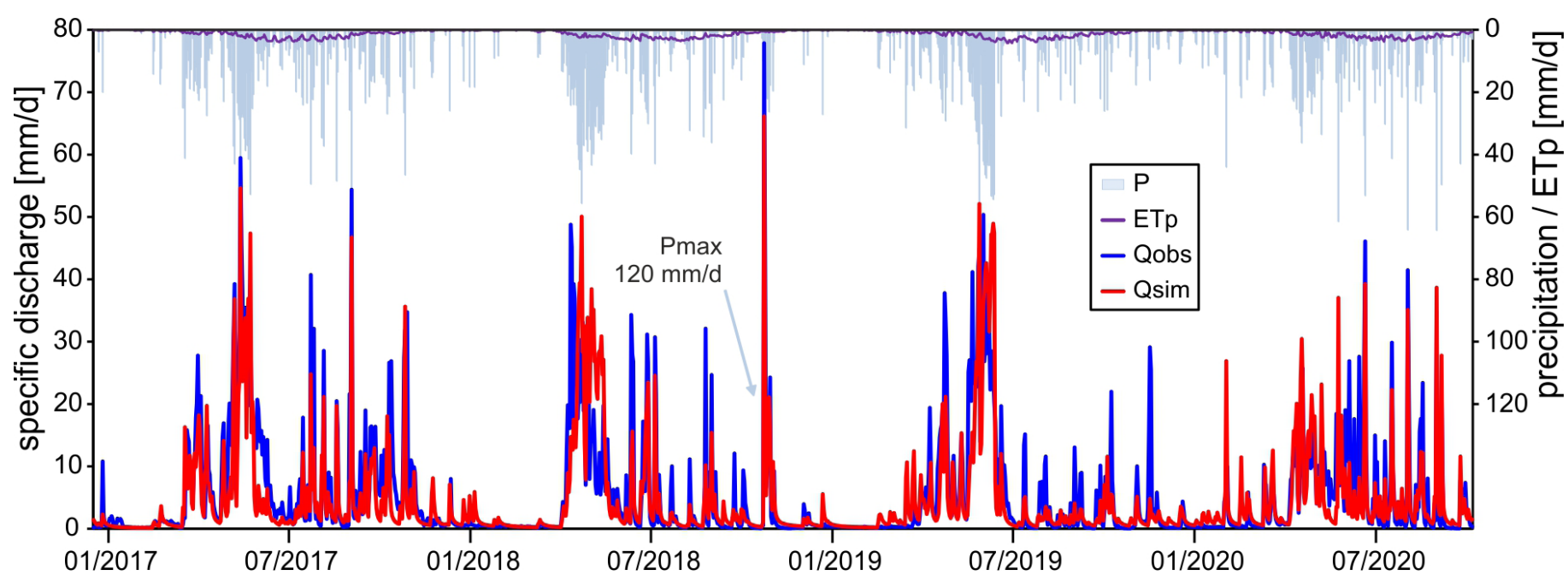

Fig. 11. Comparison of the observed discharge at the weir (Qobs) and the simulated one (Qsim) using the GR4J+ model for the period 16/12/2016 to $10 / 10 / 2020$. For easier comparison, here we use the specific discharge in $\mathrm{mm} / \mathrm{d}$, which is related to a catchment area of $4,500 \mathrm{~m}^{2}$. Note that the most intense $Q$ event overlaps the maximum $P$ event of $120 \mathrm{~mm} / \mathrm{d}$ (see label).

distances, altitudes, and geomorphologic settings. In addition, it could also hint at some buffering and water storage in the deeper parts of the vadose or the phreatic zone.

\section{Hydrograph analysis}

Concerning the hydrologic behavior of the upper vadose zone, the applied methods indicate that the hydrograph can be explained with a dual porosity model like for most karst springs. Beside a base flow and quick flow component, a third (intermediary) flow component was added for a better characterization of the recession curves as is commonly done (Baedke \& Krothe, 2001, 2003). Time series hydrograph recessions show the same range as single analysis with a mean $\alpha 1$ of $4.1, \alpha 2$ of 1.6 , and $\alpha 3$ of $0.41 / d$. The quick flow $(\alpha 1)$ was only observed for rain events and not during snowmelt. During development and testing of the MRC tool, Posavec et al. (2010) analyzed karst springs in Croatia and separated the recessions into three segments as well. There, the $\alpha$ values are one order of magnitude smaller than in Furtowischacht, which reflects the hydrographs of karst springs which are more "buffered" but still exhibit large discharge ratios. This order of magnitude difference in $\alpha$ values may be explained by the significantly smaller catchment size compared to typical studies at karst springs.

Poulain et al. (2018) monitored water percolating into a cave below a 20 to $30 \mathrm{~m}$ thick vadose zone in the Rochefort Cave in Belgium (225 m a.s.1.). Two flow components were described: a quick flow $(66 \%$, linear recession coefficient $\AA$ between 0.5 and $41 / d)$ and a diffuse flow (34\%, exponential recession coefficient $\alpha$ between 0.03 and $0.11 / \mathrm{d}$ ). Even though the linear recession coefficient $\AA$ is not directly comparable to the $\alpha$ used herein, it is interesting to note that these recession coefficients are in a similar range despite the different settings.

Liu et al. (2016) analyzed drip water in the Velika Pasica Cave (622 m a.s.1., Slovenia) with 2 to $12 \mathrm{~m}$ overburden of dolomite rock, which they interpreted as epikarst. Compared to our data, their values are lower: $\alpha 1$ ranged from 0.05 to $0.1, \alpha 20.01$ to 0.03 , and $\alpha 30.01$ to $0.0031 / \mathrm{d}$ (after converting recession parameters $\mathrm{k}$ into $\alpha$-values). These significantly lower values can be explained by the presence of the dolomite host rock and by the thicker soil cover compared to the catchment of Furtowischacht.

\section{Winter discharge}

An interesting finding is that in winter $Q$ does not get very low and typically fluctuates between 0.01 and $0.021 / \mathrm{s}$ even though there are periods of up to 89 days without rain (and likely snowmelt) events. In contrast, the $Q$ minima reached in autumn after only 9 days without recharge are one order of magnitude lower $(0.002 \mathrm{l} / \mathrm{s})$. In winter after a short recession, the hydrograph fades to semi-constant conditions, which suggests a continuous input of water. Two possible explanations are provided here. Firstly, it could be melt water from the base of the snow cover due to the thermal flux from the rock below, eventually enhanced by air circulations within the conduit network in the upper vadose zone. This is supported by the observation of meter-sized bell shaped cavities at the base of the snow cover that are located above the cave entrances, few karren fields, and boulders. Secondly, Klimchouk (2000) described that the formation of condensation water within caves and fractures due to air circulation can be significant for the water budget. According to calculations by B. Dublayansky (Klimchouk, 2000), condensation contributed 3.8 to $4.71 / \mathrm{s} / \mathrm{km}^{2}$ to the annual flow in a high mountainous karst in West Caucasus. Using the average of $4.25 \mathrm{l} / \mathrm{s} / \mathrm{km}^{2}$ and our study area of $0.0045 \mathrm{~km}^{2}$ condensation could contribute $0.021 / \mathrm{s}$ to the karst flow regime. This is a very similar value to what is measured at the weir.

\section{Natural tracer}

A high variability is also observed in the physicochemical parameters. During high intensity rainfall events, a drop of EC and an increase of $\mathrm{T}_{\mathrm{w}}$ can be explained by large fractures that rapidly transmit only slightly mineralized and warm event water towards the weir. The short rapid increase immediately before the drop of EC indicate a piston flow (Ford \& Williams, 
2007). Often this drop is followed by an EC rise and can be interpreted by stored mineralized water that is pushed out of pores. In contrast, low or long rain events either show a continuous increase of EC, or if there is a drop at the beginning, EC rises above the initial level. This can be interpreted as a response of stored water in the epikarst being pushed out of the matrix by the event water or by longer travel times of water draining from more distant regions. However, it is contradicting normal spring behavior where rainfall events and consequently event water usually dilutes longer stored water and EC decreases during these times. Another argument for water storage is the time shift of the reaction of $\mathrm{EC}$ and $\mathrm{T}_{\mathrm{w}}$ after the increase of $\mathrm{Q}$, which is in average around $1 \mathrm{~h}$ during snowmelt or rain events.

\section{Artificial tracer}

Tracer test with rock salt allowed detecting at least one Kluftkarre at the surface that is hydrologically connected to the stream in Furtowischacht. Surprisingly, two tracers injected almost above the Vereinigungsraum were not detected at the weir and for three other tests the interpretation is ambiguous. There can be several reasons why, out from six surface injections, only one could be detected at the weir. Beside the possibility of drainage to another karst conduit, it could be that not enough water for flushing was used and / or that the tracer was retained in the epikarst and diluted over time. Another explanation is that at the injection points where no clear change in EC was recorded, the storage capacity within the system down to the weir is much higher and the amount of injected salt was too low for a clear detection.

Characteristics of the conduit system can be derived from tracer transit times (Goldscheider, 2015). We determined transit times for two segments of the upper vadose zone: 1) from the surface to Vereinigungsraum and 2) from there to the weir. The salt tracer injected at the surface showed that the transit velocity down to Vereinigungsraum is almost five times lower than further down to the weir. On the one hand, in the upper part, the gradient is lower but on the other hand, it can be reasoned that the inaccessible upper part consists of fissures and much smaller conduits which reduce flow velocities. In contrast, in the spacious canyons and pits below, flow velocities are much higher. This could be seen as an argument for water storage in an epikarst layer. However, this tracer test was not conducted during a flood event and a possible quick flow through major conduits was not activated.

Goldscheider et al. (2008) conducted a tracer experiment from the Vers-chez-le-Brandt cave (Switzerland) at a site with $2 \mathrm{~m}$ soil cover and $30 \mathrm{~m}$ unsaturated limestone. At a $\mathrm{Q}$ of $0.08 \mathrm{l} / \mathrm{s}$, the dye tracer arrived after 60 min giving a $v_{1}$ of $0.009 \mathrm{~m} / \mathrm{s}$. If we also consider only the vertical component $(40 \mathrm{~m})$ at Furtowischacht, the tracer travel time $\mathrm{v}_{1}=0.004$ $\mathrm{m} / \mathrm{s}$ from the surface to Vereinigungsraum, is half the value compared to the one of Goldscheider et al. (2008). Using the recovery curves of injected Uranine,
Poulain et al. (2018) could differentiate between tracer velocities of quick flow components $\left(\mathrm{v}_{1}=0.015\right.$ $\mathrm{m} / \mathrm{s})$ and of slow flow $(0.0028 \mathrm{~m} / \mathrm{s})$ in their vadose catchment. Again, both values are in an agreement with our findings.

The repetition of tracer tests at different flow conditions is useful to quantify the variability of the flow system and hydrological conditions (Stevanović, 2015). Concerning the tracer transit times $\left(t_{1}\right)$ (or the velocities $\mathrm{v}_{1}$ ) between Vereinigungsraum and the weir, we found that the values between low flow $(0.01 \mathrm{l} / \mathrm{s})$ and high flow $(1.1 \mathrm{l} / \mathrm{s})$ differ by a factor of 34 . The ones extrapolated to the overall Qmax and Qmin differ by a factor of 1,611. These extreme differences can be explained by more or less free-fall of the water at the vertical pits and high velocities in the canyons during high Q ( 1 to $2 \mathrm{~cm}$-long scallops directly above the water level during low flow conditions indicate velocities in the order of a few meters per second during flood events; e.g., Palmer, 2007). In contrary, during low $\mathrm{Q}$ a thin water film slowly moves down the walls, is stored and diluted in pools at the bottom of the pits, and a tiny runnel moves through the canyons.

\section{Rainfall-runoff model}

The application of the GR4J+ model could further quantify the observations. This study reports the first use of the GR4J+ model in the upper vadose zone and for a very small catchment of only $4500 \mathrm{~m}^{2}$. The production store $(\mathrm{x} 1$; usually seen as soil moisture accounting store) has a capacity of $120 \mathrm{~mm}$ which is quite low compared to the other studies (Perrin et al., 2003; Table 4). In our context, it can be interpreted that the production store reflects a small soil cover having some relevance due to its possible evapotranspiration. The routing store (x3; usually reflecting a kind of phreatic aquifer) has a lower thickness of only $40 \mathrm{~mm}$ but nevertheless indicates a storage component. Here it could be interpreted as the aquifer in the epikarst. However, this storage volume of $40 \mathrm{~mm}$ contradicts the calculations of the storage volume from the recession analysis that is one order of magnitude lower. However, storage capacity and actual use of the storage might be different. The slightly negative exchange coefficient (x2) indicates water loss or exit within the catchment. The time base of unit hydrograph $(\mathrm{x} 4)$ is $1.0 \mathrm{~d}$, which is shortest simulated in Table 4. This is in accordance with the high value for the quick flow $(\alpha 1)$ of the hydrograph analysis.

Even though the general discharge dynamics are well simulated with the GR4J+ a possible drawback is, that it uses data with a daily resolution that might not be able to reproduce the highly dynamic behavior of this site. A higher resolution (e.g., hourly values) might improve the model, but also would exacerbate uncertainties in input parameters $\left(\mathrm{T}_{\text {air }}\right.$ and $\left.\mathrm{P}\right)$. A major uncertainty within the model is that $P$ was not measured directly within the catchment of the cave stream. The meteorological station, where $\mathrm{P}$ was measured, is $1.5 \mathrm{~km}$ away and the topographic settings are different. The possible error in $\mathrm{P}$ also effects the calculation of the catchment area and 
the determination of the time shift between $\mathrm{P}$ and the reaction of $\mathrm{Q}$. Due to orographic as well as altitudinal effects of $P$, it can be assumed that values of precipitation are actually higher than measured. This likely explains the water balance error of $86 \%$.

\section{Water storage in the epikarst}

The existence of a hydrologically significant epikarst layer remains unclear. On the one hand, we found indications for a significant storage like the delay in the reaction of the chemograph compared to the hydrograph or the parameters derived from the rainfall-runoff model as well as some indications for piston flow. Both point towards water stored in a matrix in the upper vadose zone that can be interpreted as an epikarst layer below the soil cover. On the other hand, the water storage calculated from the recession analysis is only $22 \mathrm{~m}^{3}$ or $5 \mathrm{~mm}$ (if it is related to the catchment area of $4,500 \mathrm{~m}^{2}$ ). Assuming that half of the area is covered by humus soil with an average thickness of $0.15 \mathrm{~m}$, the volume of the soil sums up to $657 \mathrm{~m}^{3}$. This simple estimation shows that the water storage makes up only $3 \%$ of the soil volume and could be also stored therein. Moreover, the bedrock morphology between the soil layer and the epikarst may play a role (fill-spill-drain mechanism; Tromp-Van Meerveld \& McDonnell, 2006). Further hydrochemical data would be needed to identify the potential water storage contribution of the partial soil layer.

From a morphologic point of view, the high alpine catchment shows karren, small dolines, few shaft entrances, and a partial humus soil cover of up to $0.3 \mathrm{~m}$. According to the classification scheme of Klimchouk (2004), these features can be interpreted both, as "incipient" as well as "old mature epikarst". This contradiction can be explained by the glacial erosion that clearly affected the catchment of the cave stream and removed some features of the old mature epikarst.

Another study from Hochschwab massif by Exel et al. (2016) also investigated the storage in the upper vadose zone. It was conducted in a cave at $1,895 \mathrm{~m}$ a.s.1., $4 \mathrm{~km}$ west of Furtowischacht below a palaeolandscape without major glacial erosion. Isotope studies and hydro-chemograph comparison indicated a significant mixing and storage of water, which was explained by the soil cover and possibly an epikarst layer.

Hence, the presence and thickness of a potential of the epikarst at Hochschwab massif varies and might be affected by past glacial erosion. Further investigations of the water percolation e.g., the analysis of stable isotopes may provide an insight into the water mixing rate and storage component. In particular, the runoff in winter could be differentiated and answer whether it is stored, condensation or snowmelt water.

\section{CONCLUSION}

The presented study was designed to characterize the water flow regime with its hydraulic characteristics and water storage components in the upper vadose zone of a high alpine catchment. Therefore, a direct monitoring of recharge processes and a survey of the conduit system through a weir in a vadose canyon $100 \mathrm{~m}$ below the entrance was performed. The following conclusions can be drawn:

1) The runoff at the weir in Furtowischacht is extremely dynamic $(0.002$ to $191 / \mathrm{s})$ with a variability degree of 9,500 and the average $Q$ is $0.281 / \mathrm{s}$, which accounts for a catchment area of only $4,500 \mathrm{~m}^{2}$.

2) Due to hydrologic events, the physicochemical parameters react with an average delay of $50 \mathrm{~min}$ after an increase of $Q$ and the behavior of the chemograph can partly be interpreted as piston flow.

3) Repeated tracer tests show that the transport velocities differ by three orders of magnitude between base flow and high flow conditions. Tracer velocities are almost five times higher in the accessible parts of the cave than in the matrix and narrow conduits above.

4) During winter conditions, water from condensation or meltwater influence discharge and potentially maintains permanent flow at the weir.

5) Flow characteristics can be well described with a dual porosity model.

6) Results of the global rainfall-runoff model show a low storage volume that may be accommodated by the soil cover and therefore water storage in the epikarst layer is unclear.

\section{ACKNOWLEDGMENT}

The authors would like to thank Vienna Water (especially Christian Böck, Gerhard Kuschnig, and Christoph Rigler) and the Austria Research Promotion Agency (FFG) for their financial support. Many thanks to Ralf Benischke, Steffen Birk, Kurt Decker, Bernhard Grasemann, and Rudolf Pavuza for discussions. Ernst Formann (Vienna Water) and Anton Englert (Natural History Museum Vienna) helped with the preparation of the weir. Michael Nagl and Kathi Bürger supported the fieldwork. The landowner (Forstverwaltung Pyhrr, Wilhelm Habenbacher) granted access to the area. The authors would like to thank the editor and two anonymous reviewers for their valuable comments.

Authorship statement: EK and LP designed and directed the study. EK, LP, BF, and PO performed the measurements. EK analysed the data and carried out the simulations with input from LP and TW. EK and LP wrote the paper with input from all authors.

\section{REFERENCES}

Atkinson, T.C., 1977. Diffuse flow and conduit flow in limestone terrain in the Mendip hills, Somerset (Great Britain). Journal of Hydrology, 35, 93-110. https://doi.org/10.1016/0022-1694(77)90079-8

Baedke, S.J., Krothe, N.C., 2001. Derivation of effective hydraulic parameters of a karst aquifer from discharge hydrograph analysis. Water Resources Research 37(1), 13-19. https://doi.org/10.1029/2000WR900247 
Baedke, S.J., Krothe, N.C., 2003. Reply to comment by A. Sahuquillo and J. Jaime Gomez-Hernandez on "Derivation of effective hydraulic parameters of a karst aquifer from discharge hydrograph analysis. Water Resources Research 39(6), 1153.

https://doi.org/10.1029/2003WR002028, 2003

Bauer, H., Schröckenfuchs, T.C., Decker, K., 2016. Hydrogeological properties of fault zones in a karstified carbonate aquifer (Northern Calcareous Alps, Austria). Hydrogeology Journal, 24, 1147-1170.

https://doi.org/10.1007/s10040-016-1388-9

Birk, S., Hergarten, S., 2010. Early recession behaviour of spring hydrographs. Journal of Hydrology, 387, 2432. https://doi.org/10.1016/j.jhydrol.2010.03.026

Benischke, R., Stadler, H., Völkl, G., 2016. Karstquellen. In: Spötl, C., Plan, L., Christian, E. (Eds.), Höhlen und Karst in Österreich. Oberösterreichisches Landesmuseum, Linz, p. 73-96.

Bryda, G., Van Husen, D., Kreuss, O., Koukal, V., Moser, M., Pavlik, W., Schönlaub, M., Wagreich, M., 2013. Erläuterungen zu Blatt 101 Eisenerz. Geologische Bundesanstalt, Wien.

Doummar, J.J., 2012. Identification of indicator parameters for the quantitative assessment of vulnerability in karst aquifers. Dissertation, GeorgAugust-Universität Göttingen, 116 p.

Exel, T., Stadler, H., Wriessing, K., Ottner, F., Plan, L., 2016. Untersuchungen zum oberflächennahen Wasserspeichervermögen am Hochschwab-Karstplateau. Die Höhle, 67, 77-87.

Fiorillo, F., 2014. The recession of spring hydrographs, focused on karst aquifers. Water Resources Management, 28, 1781-1805. https://doi.org/10.1007/s11269-014-0597-z

Ford, D.C., Williams, P., 2007. Karst hydrogeology and geomorphology. John Wiley \& Sons Ltd., Chichester, 562 p. https://doi.org/10.1002/9781118684986

Geyer, T., 2008. Process-based characterisation of flow and transport in karst aquifers at catchment scale. Dissertation, Georg-August-Universität Göttingen, 118 p.

Goldscheider, N., 2015. Overview of methods applied in karst hydrogeology. In: Stevanović, Z. (Ed.), Karst aquifers - Characterization and engineering. Springer International, Cham, p. 127-145. https://doi.org/10.1007/978-3-319-12850-4

Goldscheider, N., Meiman, J., Pronk, M., Smart, C., 2008. Tracer tests in karst hydrogeology and speleology. International Journal of Speleology, 37, 27-40. https://doi.org/10.5038/1827-806X.37.1.3

Hartmann, A., Goldscheider, N., Wagener, T., Lange, J., Weiler, M., 2014. Karst water resources in a changing world: Review of hydrological modeling approaches. Reviews of Geophysics, 52, 218-242. https://doi.org/10.1002/2013RG000443

Höfer-Öllinger, G., 2020. Karst hydrogeological investigations in Salzburg, Austria. Grundwasser, 25, 15-29. https://doi.org/10.1007/s00767-019-00439-6

Klemes, V., 1986. Operational testing of hydrological simulation models. Hydrological Science 31, 13-24. https://doi.org/10.1080/02626668609491024

Klimchouk, A., 2000. The Formation of Epikarst and Its Role in Vadose Speleogenesis. In: Klimchouk, A., Ford, D.C., Palmer, A.N., Dreybrodt, W. (Eds.), Speleogenesis. Evolution of karst aquifers. National Speleological Society, Huntsville, p. 91-99.

Klimchouk, A., 2004. Towards defining, delimiting and classifying epikarst: Its origin, processes and variants of geomorphic evolution. Speleogenesis and Evolution of Karst Aquifers, www.speleogenesis.info/directory/ karstbase/publication.php?id=4501 [accessed: Dec. 18, 2020]

Kresic, N., Bonacci, O., 2010. Spring discharge hydrograph. In: Kresic, N., Stevanović, Z. (Eds.), Groundwater hydrology of springs. Elsevier, Amsterdam, p. 129-163. https://doi.org/10.1016/B978-1-85617-502-9.00004-9

Liu, A.W., Brancelj, A., Ellis Burnet, J., 2016. Interpretation of epikarstic cave drip water recession curves: a case study from Velika Pasica Cave, central Slovenia. Hydrological Sciences Journal, 61, 2754-2762. https://doi.org/10.1080/02626667.2016.1154150

Maillet, E. (1905) Essais d'hydraulique souterraine et fluviale. Librairie Sci., A. Hermann, Paris, 286 p.

Majone, B., Bertagnoli, A., Bellin, A., 2010. A non-linear runoff generation model in small Alpine catchments. Journal of Hydrology, 385, 300-312.

https://doi.org/10.1016/j.jhydrol.2010.02.033

Malik, P., 2015. Evaluating discharge regimes of karst aquifer. In: Stevanović, Z. (Ed.), Karst aquifers Characterization and engineering. Springer, London, p. 205-249. https://doi.org/10.1007/978-3-319-12850-4

Mazzilli, N., Guinot, V., Jourde, H., Lecoq, N., Labat, D., Arfib, B., Baudement, C., Danquigny, C., Dal Soglio, L., Bertin, D., 2019. KarstMod: A modelling platform for rainfall - discharge analysis and modelling dedicated to karst systems. Environmental Modelling and Software, 122, 1-7.

https://doi.org/10.1016/j.envsoft.2017.03.015

Oudin, L., Hervieu, F., Michel, C., Perrin, C., Andréassian, V., Anctil, F., Loumagne, C., 2005. Which potential evapotranspiration input for a lumped rainfall-runoff model? Part 2 - Towards a simple and efficient potential evapotranspiration model for rainfall-runoff modelling. Journal of Hydrology, 303, 290-306. https://doi.org/10.1016/j.jhydrol.2004.08.026

Palmer, A.N., 2007. Cave geology. Cave Books, Dayton, 454 p.

Parise, M., Gabrovsek, F., Kaufmann, G., Ravbar, N., 2018. Recent advances in karst research: from theory to fieldwork and applications. In: Parise, M., Gabrovsek, F., Kaufmann, G., Ravbar, N., (Eds.), Advances in karst research: Theory, fieldwork and applications. Geological Society London, Special Publications, 466 p. https://doi.org/10.1144/SP466.26

Perrin, C., Michel, C., Andréassian, V., 2003. Improvement of a parsimonious model for streamflow simulation. Journal of Hydrology, 279, 275-289. https://doi.org/10.1016/S0022-1694(03)00225-7

Perrin, J., 2003. A conceptual model of flow and transport in a karst aquifer based on spatial and temporal variations of natural tracers. $\mathrm{PhD}$ Dissertation, University of Neuchâtel, 227 p.

Perrin, J., Jeannin, P.Y., Zwahlen, F., 2007. Epikarst storage in a karst aquifer: a conceptual model based on isotopic data, Milandre test site, Switzerland. Journal of Hydrology, 279, 106-124. https://doi.org/10.1016/S0022-1694(03)00171-9

Plan, L., 2002. Speläologisch-tektonische Charakterisierung der Karstwasserdynamik im Einzugsgebiet der bedeutendsten Quellen der Ostalpen (Kläfferquelle, Hochschwab). Speldok 11, Verband Österreichischer Höhlenforscher, Wien, 83 p.

Plan, L., 2016. Hochschwab. In: Spötl, C., Plan, L., Christian, E. (Eds.), Höhlen und Karst in Österreich. Oberösterreichisches Landesmuseum, Linz, p. 645-660.

Plan, L., Decker, K., 2006. Quantitative karst morphology of the Hochschwab plateau, Eastern Alps, Austria. Zeitschrift für Geomorphologie, Supplement, 147, 29-54. 
Plan, L., Kuschnig, G., Stadler, H., 2010. Kläffer Spring the major spring of the Vienna water supply (Austria). In: Kresic, N., Stevanović, Z. (Eds.), Groundwater hydrology of springs. Elsevier, Amsterdam, p. 411-427. https://doi.org/10.1016/B978-1-85617-502-9.00020-7

Plan, L., Oberender, P., 2018. Aufbau einer Messstelle für hydrologische Untersuchungen im Furtowischacht, Hochschwab. Höhlenkundliche Mitteilungen, Wien, 74, 120-124.

Posavec, K., Giacopetti, M., Materazzi, M., Birk, S., 2017. Method and Excel VBA algorithm for modeling master recession curve using trigonometry approach. Groundwater, 55, 891-898. https://doi.org/10.1111/gwat.12549

Posavec, K., Parlov, J., M., Zoran, N., 2010. Fully automated objective-based method for master recession curve separation. Groundwater, 48, 598-603. https://doi.org/10.1111/j.1745-6584.2009.00669.x

Poulain, A., Watlet, A., Kaufmann, O., Van Camp, M., Jourde, H., Mazzilli, N., Rochez, G., Deleu, R., Quinif, Y., Hallet, V., 2018. Assessment of groundwater recharge processes through karst vadose zone by cave percolation monitoring. Hydrological Processes, 32, 2069-2083. https://doi.org/10.1002/hyp.13138

Rehrl, C., Birk, S., 2010. Hydrogeological characterisation and modelling of spring catchments in a changing environment. Austrian Journal of Earth Sciences, 103(2), 106-117.

Sauter, M., Geyer, T., Kovács, A., Teutsch, G., 2006. Modellierung der Hydraulik von Karstgrundwasserleitern - Eine Übersicht: Herrn Professor Gerhard Einsele zum 80. Geburtstag gewidmet. Grundwasser, 11, 143-156. https://doi.org/10.1007/s00767-006-0140-0

Smart, P.L., Hobbs, S.L., 1986. Characterisation of carbonate aquifers: A conceptual base. Proceedings of the Environmental Problems in Karst Terranes and Their Solutions Conference, October 28-30, 1986, Bowling Green, Kentucky, p. 1-14.

Spötl, C., Pavuza, R., 2016. Höhlenatmosphäre. In: Spötl, C., Plan, L., Christian, E. (Eds.), Höhlen und Karst in Österreich. Oberösterreichisches Landesmuseum, Linz, p. 123-138.
Stevanović, Z., 2015. Karst aquifers - Characterization and engineering. Springer, London, 698 p. https://doi.org/10.1007/978-3-319-12850-4

Trcek, B., 2003. Epikarst zone and the karst aquifer behaviour. Geoloski zavod Slovenije, Ljubljana, 100 p.

Tromp-Van Meerveld, H.J., McDonnell, J.J., 2006. Threshold relations in subsurface stormflow: 2 . The fill and spill hypothesis. Water Resources Research, 42, W2411.

Wagner, T., Brodacz, A., Krainer, K., Winkler, G., 2020. Active rock glaciers as shallow groundwater reservoirs, Austrian Alps. Grundwasser, 25, 215-230. https://doi.org/10.1007/s00767-020-00455-x

Wagner, T., Mayaud, C., Benischke, R., Birk, S., 2013. Ein besseres Verständnis des Lurbach-Karstsystems durch ein konzeptionelles Niederschlags-Abfluss-Modell. Grundwasser, 18, 225-235. https://doi.org/10.1007/s00767-013-0234-4

Wagner, T., Pauritsch, M., Winkler, G., 2016. Impact of relict rock glaciers on spring and stream flow of alpine watersheds: Examples of the Niedere Tauern Range, Eastern Alps (Austria). Austrian Journal of Earth Sciences, 109, 84-98. https://doi.org/10.17738/ajes.2016.0006

Williams, P.W., 2008. The role of the epikarst in karst and cave hydrogeology: A review. International Journal of Speleology, 37, 1-10. https://doi.org/10.5038/1827-806X.37.1.1

Winkler, G., Wagner, T., Pauritsch, M., Birk, S., KellererPirklbauer, A., Benischke, R., Leis, A., Morawetz, R., Schreilechner, M.G., Hergarten, S., 2016. Identification and assessment of groundwater flow and storage components of the relict Schöneben Rock Glacier, Niedere Tauern Range, Eastern Alps (Austria). Hydrogeology Journal, 24, 937-953. https://doi.org/10.1007/s10040-015-1348-9 